\title{
DE RECHTSGEDACHTE DER CODIFICATIE-BEWEGING IN FRANKRIJK, VOOR DE REVOLUTIE
}

\author{
DOOR \\ Mr. J. VAN KAN, \\ Hoogleeraar te Leiden.
}

I.

Omstreeks de XII ${ }^{\ominus}$ eenw was er, ruwweg gesproken, in de meeste landen van West-Esuropa nagenoeg geen geschreven recht, met name geen gesehreven privaatrecht. Wat te voren als zoodanig had gegolden, was in onbruik geraakt: de massale aanvaarding door sommige veroveraars van een ruw geboekstafd Romeingeh recht ten behoeve van de onderworpen bevolking was een nawerking van de Oudheid, die in de besohaafde Middoleouwen geen sporen heeft gelaten; evenmin als de leges barbarorum, een begin pan een strafrechtscodificatie, wier gelding het tijdstip, waarvan wij uitgaan, niet heeft overleefd; evenmin als het koningsrecht der capitularia; evenmin als sommige Keltische rechtssamenvattingen. Glaandeweg wordt dat anders. Men begint te verlangen en te streven naar de opteekening van het recht. De gang van dat streven is in alle landen van Europa een moeizame en ingewikkelde geweest, heeft ook in versehillende landen langs versehillende banen geloopen.

Dit opstel yraagt voor die geschiedenis in Frankrijk de aandacht. Daar kwam de zucht to rechtsopteekening op ruime schaal tot uiting in de twaalfde eeuw. Sindsdien is het denkbeeld niet meer opgegeven, totdat het eindelijk zijne rust heeft gevonden in de wetboeken der Revolutie. De gesehiedemis dier beweging heeft in Frankrijk vitnemende bewerking gevonden, waaraan ik niets van beteekenis zou hebben toe te voegen. Het verloop dier ontwikkeling wordt hier dan niet nog eens behandeld. Maar het is wenschelijk, dieper dan tot nog toe gesehied is, door te dringen in den 'geest der beweging, te zoeken 
naar het doel, dat zij heeft nagejaagd, naar de gedachte, welke zij heeft willen verwezenlijken, naar de behoeften, welke zij heeft willen berredigen. De vraag, welke wij onder het oog gaan zien, luidt dan: wat ging er om in de hoofden en de harten der menschen, van de roreten, van de tot leiding geroepenen, van het volk, toen men zich an de heerschappij van het gewoonterecht ontworstelde en riep om geschreven wetten en wetboeken? Wij hopen later to zien, dat het 'inzicht in die dingen nog verder strekkende beteekenis krijgt en ons nuttige lessen kan leeren voor het rechtsleven van onzen tijd en van de naaste toekomst. Want de codificatie, die massale samentrekking van rechtsnormen in wetboeken, is niet enkel een vorm van wetgeving zonder meer, doch die vorm van wetgering heeft geweldigen invloed geoefond op de rechtsvoorstelling van den tijd harer wording en harer heerschappij en houdt ook nu nog bij voortduring de voorstellingen der levende geslachten in vele opzichten gevangen. Daarop hoop ik later terug te komen. Voorloopig vrage alleen de geschiedenis onze aandacht.

Die geschiedenis wordt hier laat ingezet, omstreeks het midden der $\mathrm{X} V \mathrm{e}$ eeuw. Dit gebeurt om zuiver uitwendige redenen. Het materiaal der rechtsbronnen voor den tijj, die besloten ligt, van ons bijzonder atandpunt bezien, tusschen de vroegste rechtsopteekeningen en de vastlegging van het costumiere recht door toedoen van de centrale overheid, of, algemeen-historisch gesproken, tusschen de opkomst der communale periode en het einde van den honderdjarigen oorlog, dat materiaal is in ons land in een mate, welke de volledigheid eenigszins benadert, niet anwezig. Het was daarom ondoenlijk, voor de bewerking van dit tijdperk in de jaren, die achter ons liggen, de stof te verzamelen. Het overigens zeer belangwekkend stuk codificatie-geschiedenis of, zoo men wil, voor-geschiedenis der codificatie, dat de chartes des villes, de statuts municipaux en de teboekstelling van eenige coutumes door de gewestelijke overheid omvat, wordt dus niet behandeld. Ik hoop deze leemte aan fe vullen, wanneer eerlang Fraukrijk's boekerijen weer voor ons toegankelijk zullen zijn.

\section{II.}

In het begin der XVe eeuw openbaart zich hier en daar een streven der overheid naar opteekening van het costumiere privaatrecht en; zooveel doenlijk, van het strafrecht. Die ovorheid was de gewestelijke. In 1411 komt de teboekstelling van de coutume van Maine et Anjou tot stand, in 1417 volgt Poitou, dan Bourges in 1450. 
In 1453 neemt de koning de zaak ter hand. Daarmede wordt een beweging levendig, die meer dan anderhalve eeuw de nationale aandacht zal vragen en eerst met de Revolutie geheel tot stilstand zal komen. Omtrent die beweging bezitten wij voldoende gegevens, om een inzicht in haar streven te krijgen. Dadelijk treft het, dat ook het ingrijpen van het centrale gezag den koers niet heeft gewijzigd. De opteekening blijft, voor en na, opteekening van plaatselijk en gewestelijjk reoht. Alleen Lodewijk XI heeft weidschere plannen gekoesterd, maar ^ij zijn tot geenerlei begrin van uitwoering gekomen en xij hebbeu ook in hun niet uitgevoerden opzet geen navolging gewekt. De beweging werd niet ondernomen om tot eenheid van nationale rechtsregeliug te geraken. Men voelde wel de nationale verscheidenheid als een weinig gewensehten toestand. De ordonnance, warmede Karel VIII te Montils-les-I'ours de hervorming inluidt, klaagt, wel in duidelijke bewoordingen over de "plusieurs usages, stiles et coustumes, qui sont divers selon la diversité des pays de nostre royaume" ${ }^{1}$ ), maar niet daartegen zal het koninklijk ingrijpen zich richten. En in de zeer talrijke ordonnances en patentbrieven, die zich met de rechtsopteekening bemoeien, keert die klacht niet meer terug. Zij lromt als drijfkrneht vall de opteekeuing, welke nu staat te geschieden, uiet in aanmerking.

De volle en onafgebroken aandacht der rechtsopteckenuren is gevestigd op een andere riekte van het rechtsleven, welke men hospte door de opteekening te kumen heelen: de gewoldige onzekerheid van het plaatselijk recht zelve. Har voelde men als de meest nijpende kwaal; het recht stond niet vast, niemand kende het, partijen niet, de rechter's niet. Dat werd een bron van veelsoortige ellende. Het middel scheen voor de hand te liggen : do opteekening moest de duidelijke vastlegging brengen van wat nu een vlottend en onduidelijk bestaun voerde.

Die klacht en die hoop zijn hot hoofdmotief, ja bijun het eenis motief roor het rechtopteekenend ondernemen van bet centrale gezag. Zij klinken zeer scherp door de officiëele stukken heen, zoo seheru, dat zich niet vergissen kan wie die stukken doorbladert. Zoo zet d. bovengenoemde ordonance van 1453 het dadelijk in: „car sonventekfois advient que les parties prennent coustumes contraires en un mesm. pays, et aucunesfoys les coustumes muent et varient à leur appétit." Die onzekerheid heeft ten gevolge, dat elk proces begint met het bewijs van de reehtsregelingen, waarop partijen van plan zijn een beroep te

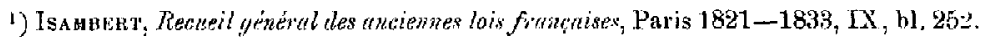


doen, en dit bracht veel kosten, veel vertraging en weinig zekerheid: net les leur convient prouver, par quog les procez sont souventesfoys moult allongez, et les parties constituées en grands fraiz et despens." Voor een op dit stuk naïeve en door de rechtsopteekening in häre belofte nog niet bedrogen generatie lag het middel voor het grijpen: „si les coustumes, usages et. stiles .... estoient rédigez par escrit"! Dan zou met één slag het kward worden uitgeroeid: "les procez en seroient de trop plus briefz, et les parties soubslevées de despenses et mises,.. et aussi les juges en jugeroyent nieux et plus certainement" en zou worden bereikt wat de koning bedoelde: "nettre certaineté ès jugemens tant que faire se pourra, et oster toutes matières de variations et contrariétez". 1).

Daarmede was het koninklijk codificatie-programma vastgesteld. Het was de weerklank van don wenseh des rolks. Dien wensch vinden wij nitgesproken door den derden stand in de vergadering der Etats-Généraux van Tours, in 1484, bij den aanvang van de regeering van Karel VIII: ${ }_{n}$ de faire rédiger par escrit les coustumes... Semble ausdits estats que les coustumes et styles du royaume doivent être rédigées par eserit et enregistrées" 2). En ook hier wordt duidelijk de verwahting aangegeven: ${ }_{n}$ afin que à icelles (les coustumes) il ne faille point appointer les parties contraires, et faire enquestes .... et souvent advient que l'on trouve que les parties ont prouvé coustumes au contraire" ${ }^{3}$ ). Daarmede was den koning, die voorziening toezegde, het richtenoer gegeven.

De algemeone ordonnance ran 28 Januari 1493 — ook zij werd gegeven op het kasteel Montils-les-Tours - omschrijft het doel van Karel's ingrijpen, in nanslyiting bij den opzet van zijn grootvader: "que les coustumes, usages et stilles de tous et chauns les pays, endroits, bailiages, prevostez et senechaussées de nostredit royaume (dus wezenlijk plaatselijk), fussent toutes redigées et mises par écrit". En de motiveering volgt: "afin d'abreger les proces et procedures (nader omsehreven als: „que au moyen de ce, les procez en seroient par plus briefs, les parties sonlagées et relevées de dépęns, frais et mises, qu'il leur convenoit faire pour prouver lesdites coustumes, usages et stiles" $\rangle$.... et mettré certaineté ès jugement d'iceux, tant que faire

1) De aanhalingen alle bij Isnunert, IX, bl, 252 .

3) Cahier Tiers, Justice 21, bij lsamaret, 1X, bl, 61. De Staten vragen hier dus wel degelijk boekstaving der nog niet opgeteekendecoutumes, niet enkel afschrift van het reeds opgeteekende. Z00 Vrouct, Hist. du droit civ. frang., Paris 1905, bl. 157.

3) T. z. p. 
se pourra, et oster toutes matieres de variations et contrarietez, qui s'en sont ensuivies le temps passe, à cause de la diversité desdites coustumes" 1) (= verscheidenheid ter zelfde plaatse). De latere algemeene ordonnance, gedagteekend Moulins, 2 September 1497, is in nietszeggende algemeene bowoordingen gehouden: „par cy devant aroient et ont esté commises et perpétrées plusieurs grandes faultes et abuz à la tres grand foulle de nos subjectz" 2), maar de ordonnance van hetgelfde jaar, waarbij de opteekening voor Touraine wordt bevolen, is des te duidelijker: "et mesmement en ce que souvent en une mesme jurisdiction s'est trouvé coustumes contraires et differentes avoir esté prouvées, en manière que nos bailliss, seneschaux et autres nos juges ont esté en grand diffulté d'asseoir jugement pour la contrariété et diversité d'icelles coustumes" 3). En weer wordt op de buitensporige kosten, die het bewijs der coutumes vordert, de nadruk gelegd: „et aussi que nos subjets le temps passé ont esté grandement interessez et endommagez à cause des grands frais, mises et despens qu'il leur a convenu et convient faire pour la preuve desdites constumes" 4).

Met Lodewijk XII verandert de redactie, de zaak blijft dezelfde. Telkens worden de koninklijke bevelschriften ingeleid door deze motiveering, welke ik neerschrijf̣ zooals ik haar heb gevonden in haren oudsten, tevens meest sprekenden vorm: "Et singulierement cognoissans les grandes vexations, longueurs, frais et despens, que nos pauvres sujets ont eu et souffert par cy-devant, au moyen de la confusion, obscurité, et incertitude, qui se trouvoit es coustumes localles des provinces, bailliages, seneschaussées et autres pays et contrées de nostredit royaume et en la difficulté de la preuvo d'icelles." Zoo luidde het in de ordonnance van 1505 tot roorbereiding van de teboekstelling der coutume van T'ouraine 5 ), zoo ging de formule, een weinig gewijzigd, iets minder duidelijk gesteld, in verschillende latere ordonnances over $\left.{ }^{6}\right)$. Nog eens, in 1506, zou de bemoeiing met Touraine den koning

1) Nouneau coutumèr général, Paris 1724 (verder aangehaald als $C . G$.), $T, b$ b. 25-26 (Bonlogue 1498); III, bl. 371-372 (Chaulmont en Bassigny 1493); eenigszins afwijkend geredigeerd III, bl. 267-268 (Troyes 1493).

2) IsAmeEk'T, XI, bl. 457.

3) G. G., IV, bl, 639 .

4) D. t. p.

5) C. G., IV. bl. 638 .

6) Chartres et Dreux 1508 C. G., III, bl. 733; Blois 1509 C. G., III 337-338; Chaulmont 1509 C. G., III, bl. 370; Meaux 1509 C. G., III, bl. 410; Orleans 1509 c. $G$., IJI, bl. 772; do algemeene lettres van $21 \mathrm{Jan} .1510$ "pour proceder ì la 
de gelegenheid geven, den vinger te leggen op de wondeplek: „de merveilleux fraiz, à cause des preuves" 1 ). En in de algemeene ordonnance van Lyon, Januari 1510 „sur la réformation de la justice" wordt nog eens, nadat opnieuw is gewezen op de ninnumerables frais, peines et travaux qu'ils supportoient par les longueurs et multitude effrénée des procés", de kwaal van den tijd scherp geteekend. Maar ditmaal wijst de koning op de onzekerheid der ordonnance zelf, uitgevaardigd tot regeling van de vastheid der contumes. Dat was het begin der zelfcritiek, de eerste twijfel van het stelsel aan de bereikbaarbeid van het doel. De merkwaardige passus luidt: „partie de nosdites ordonnances et de nosdits predecesseurs, par la diversité des interprétations trouvées sur icelles', le train de ladite justice a esté tellement troublé et perverti, que de present nosdits pauvres sujets ont esté et sont grandement molestez et travaillez, et sur ce, sont intervenus innumerables procés, questions et differens" 2).

Frans I zet met kracht de codificatie-politiek zijner voorgangers voort. Aanvankelijk zijn zijne ordonnances in algemeene bewoordingen vervat, die ons weinig verhalen omtrent de beweegredenen van zijn ingrijpen ${ }^{3}$ ). Maar een ordonnance van 1521 stelt met veel klaarheid het probleem, gelijk het in de $15^{\theta}$ eeuw onafgebroken was gesteld: "et qu'en autres $y$ avoit diversité d'opinions sur.l'interpretation et l'observance d'icelles entre les practiciens d'iceux pays" "); onzekerheid aangaande de uitlegging, maar vooral ook aangaande de gelding zelve der coutumes. "Souventesfois", zegt koning Frans in 1534, „8ur la preuve d'une mesme coustume se trouve diversité ou contrariete" ${ }^{5}$ ) en nog later formuleert hij : „pour ... oster... toute matière de procès provenans bien souvent de l'incertitude de la preuve desdites coustumes" 6). En wanneer de ordonnance van 1534 die onzekerheid aan-

visitation (Isamberr, XI, bl. 609 leest: ordonnant la révision et l'approbation) des coustumes de ce royaume", C. G., III, bl. 26. Vgl. ook een korte samenvatting Auvergne 1510 C. G., IV, bl. 1214 : „et a fin que plus briefvement et a moindrez fraiz, et pour éviter toute contrariété."

1) C. G., IV, bl, 600 .

2) IsАмвент, IX, b1. 579.

3) Xaintonge 1520 G. G., IV, bl. 863 : „d moindres fraiz et sans ancune contrariété is pays constumiers"; Bourbonnais 1520 O. G., III, bl. 1283: "pour l'abbreviation et decision de plusieurs debats et procès qui se meuvent journellement"; Bordeaux 1520 O. G., IV, bl. 891 : "diminuer toutes altercations, debats et differens."

b) C. G., I[I, bl. 1802 .

5) Nivernais 1534, C. G., III, bl: 1164.

b) Berry 1538 C. G., IJI, bl. 972 en Senlis 1539 C. G., III, bl. 733-734. 
duidt als de groote kwaal van het rechtsleven van den tijd, wanneer wordt gezegd, dat „les sujets... n'ont aucune certitude de leurs affaires" of wanneer wordt geklaagd over do "incertitude, varieté, contrarieté ou repugnance" 1), de "contrarieté et discord" 2), dan wordt darmede uitsluitend die onzekerheid bedoeld, welke, gelijk de ordonnance zelve verduidelijkt, bestaat in de "diversité, repugnance et contrarieté de l'article ou articles desquels ils ont affaire" 2). De kosten en de vele, gerekte en uitgestelde processen, waarop ook Frans I telkens terugkomt, zijn daarvan het onvermijdelijk gevolg. En wanneer de hervormingsdecreten des konings roepen om "la tranquilité, repos et seureté de nos sujets" 3 ), dan is dat weer te verstaan als een verklaarbaar verlangen naar deze allereerste rechtszekerheid, welke vraagt naar de geldende wet in het gewest der. inwoning. Dat alles is onder Frans I gebleven gelijk het te voren was; zoolang die vraag niet hare oplossing had gevonden voor geheel Frankrijk, bleef zij, bovenaan op de lijst der rechtsverlangens, op radicale afdoening wachten. Toch vernemen wij nu voor het eerst ook andere geluiden. Nieuwe motieven komen naar voren: tot nog toe teekent men het geldende recht op, om het te kennen; met den inhoud bemoeit men zich niet. $\mathrm{Nu}$ voor het eerst begint men er oog voor te krijgen, dat de massale opteekening ook rechtshervormend kan optreden, dat er bepalingen zijn "esquels elles ont semblé estre iniques et desraisonnables", welke kunnen worden getoetst aan de "raison écrite" en de "équité naturelle" 4). Tegelijkertijd wijst Frans I op een andere wolk, dje het rechtsleven bedreigt en later de scherpe aandacht vragen zal: de veelheid en verscheidenbeid van rechtsbronnen in denzelfden plaatselijken kring: „Et en outre vous mandons que vous informez de la multitude et proximité de barres et jurisdictions royales du dit pays" 5). Dat zijn nieuwe prikkels voor het codificeerend optreden der overbeid. Maar een rol van beteekenis spelen zij nog niet. Men zal eerst de groote teleurstelling moeten doormaken, welke de opteekening van het bestaande zal brengen, roor men ernstig langs nieuwe banen zal gaan zoeken.

Hendrik II blijft de rechtshervorming voor den geest zweven. Nu hem eenmaal de oogen hierover geopend zijn, dat, se seroient trou-

1) Nivernais 15034 hierboven angehaald.

2) T. a. p. bl. 1166.

3) Berry 1538 hierb. aangeh, en Senlis 1539 hierb. aangeh.

4) Berry 1539 C. $G_{n,}$ III, bI. 989.

5) Bretagne 1539, O. G., IV, bl. 334. 
vées plusieurs coustumes dures, iniques et desraisonnables", nu begrijpt hij, dat voor het centrale gezag nog een andere taak dan de te boekstelling is weggelegd: naast de "redaction" de "reformation des coustumes". Zoo noodig moet het mes er in: "si besoin est, muer, corriger et abroger" 1). Doch ook onder Hendrik II blijft het altijd weerkeerend hoofdmotief voor de koninklijke bemoeiing de „incertitude, confusion et obscurité d'icelles coûtumes" 2), de onzekerheid betreffende het bestaan der beweerde costumiere regelingen: „auguns artigles de queras eran... en auguns endretz confuus et contrarians" 3). Dat was do kwaal des tijds: „au moyen du quoy nosdits pauvres sujets ont souffert et souffrent grandes vexations, langueurs, frais et dépens" ${ }^{4}$ ), als het oumiddellijk gevolg van het rampzalige turbe-onderzoek, dat aan elk proces moest voorafgaan en dat in Frankrijk wel tot verregaande wantoestanden en misbruiken aanleiding heeft gegeven. Herhaaldelijk komt de koning terug op de „grandes longueurs en involution de procès, confusion; difficultez et despenses de faire preuve par turbes" 5). Daartegenover is het streven des konings gericht op „lo bû (= le bien), repans (= repos) et solagements de nostres diijts subjects" ${ }^{6}$ ).

De weinige bemoeiingen van Frans II en Karel IX zinspelen weer op de "grands fraiz des turbes" 7), terwijl de laatatgenoemde zich in 1570 duidelijk plaatst op het standpunt zjjuer voorgangers: „afin d'éviter les incommoditez et differens que l'obscurité, depravation et peu d'in-

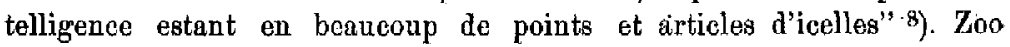
had ook, bij de aanvaarding van Karel's regeering, in 1560, de Staten-vergadering van Orleans (-Pontoise) het gewenseht. De adel drong aan op de voortzetting van de opteekeniugen en had daarbij de klaarheid en ondubbelainnigheid zoowel van het costumiere als van het "ge-

1) Péronne 1558 C. G., IT, bl, 645; Malun 1558 C. G., III, bl. 459. Vgl. ook daar: "lesdites coustumes ainsi redigéen, accordées, moderées ou corrigées".

2) Boulenais 1550 c. G., I, bl. 71 .

3) Béarn 1551, C. G., IV, bl. 1071.

1) Boulenais 1550 hierb. aangeh.

5) Grand Perche 1556 G. G., III, bl. 661; Sens 1555 C. G., III, bl. 530; Estampes 1556 G. G., III, bl. 107 ; Dourdan 1556 G. G., IIT, bl. 132 ;.Montfort 1556 C. G., III, bl. 154; Vermandois 1556 0. G., 1I, bl. 539; Mantes et Meullant 1558 C. G., III, bl. 206; Auxerre 1558 o. G., III, bl. 611. Vgl. ook Bearn 1551 C. G., IV, bl. 1071.

6) Béarn 1551 C. G., IV, bl. 1097.

7) Auxerre 1559 C. G., III, bl. 611; Auxerre 1560 C. G., III, bl. 612.

s) Bourgogne 1570 C. G., II, bl. 1182. 
schreven" recht - dit laatste voor de landen van het droit écrit op het oog 1). Dat is weer het oude gezichtspunt, waarbij het streven naar materiëele verbetering even om den hoek kijkt. Intusschen komt dit laatste duidelijk te voorschijp̣ in een rapport van de commissie voor de teboekstelling van de coutumes van Péronne (1566): "nous disans aussi leur advis et opinion de ce qu'ils trouvent dur, rigoureux et desraissonnable des coustumes cy devant par eux observées, pour comme tel estre par nous tempéré, modéré corrigé ou du tout abrogé" 2). Maar ook die commissie zag de hoofdwonde van den tijd in de onzekerheid van het plaatselijk en gewestelijk recht.

Onder de regeering van Hendrik III komt de wensch des rolks tot uiting, in de vergadering der Etats-généraux te Blois, in 1576 en in 1588. Bij deze beide gelegenheden vraggt de adel de voltooiing van het ondernomen werk ran de opteekening der coutumes ter voorkoming van het kostbare turbe-onderzoek "pour la rérification des moindres points de la controverse des usances" 3). En ook de derde stand verlangt in 1576 de coutumes te zien verduidelijkt ${ }^{4}$ ). De koning verleent hel oor aan die stem des volks, en zijne codificatie-politiek streeft weer naar hetzelfde doel: de zekere vaststelling van het plaatselijk en gewestelijk recht. Hij trekt te velde tegen "ce qui est obscur et confus" 5), tegen de "articles... peu éclaircis, mal entendus et pratiquez" 6), de "articles obscures et non intelligbles" 7). Daartegenover wil hij stellen "un language clair et intelligible" 8), „une si claire et certaine interpratation, que les doutes qu'on y a fait le temps passé, cessent pour l'advenir" 9). Want die onklaarheid moet op den duur noodlottig worden: "la diversité des arrets et jugemens on autrement pourroient avec le temps estre cause de troubler et alterer l'estat et repos public dudit pays" 10) (dit is: het gewest Bretagne). Zij drukt. zwar op de bevolking door de buitensporig hooge kosten van het

1) Proon, Hist. des álats gén., Paris 1888, II, bl. 334 en 335.

2) C. G., II, bl. 652 .

3) Prcot, III, bl. 268 en IV, bl. 39.

1) Prcor, III, bl. 267.

5) Normandie 1577 G. G., IV, bl. 111.

") Bretagne 1576 C. G., IV, bl. 425; Bretagne 1575 C. G., IV, bl. 418.

7) Orleans 1583 C. G., III, bl. 808.

-) Normandië 1577 hierb. aangeh.

9) Bretagne 1575 hierb. aangeh.

10) Bretagne 1576 hierb. angeh.; Bretagne 1575 hierb. aangeh. 
turbe-onderzoek 1). De grondoorzaak van al het onheil is "la diversité des coutumes cstans" 2).

Weer denkt Hendrik IV aan de verbetering van de "coustume rigonrense et inique" ${ }^{3}$. Maar ook voor bem staat de andere beweegreden, als de hoofdbeweegreden, voorop: „y a de grandes longueurs et fraiz inutils et superflus, qui consomment la plus grande partie du prix, au préjudice des legitimes creanciers; qu'en plusieurs autres articles desdites coustumes, il y a plusieurs dontes, difficultez, obscuritez et mesmes. des contrarietez". En hij hoopt weer voorul de "frois extraordinaires" te voorkomen ").

Gelijk het was in de landen, die onmiddellijk stonden onder de kroon van Frankrijk, zoo was het begrijpelijkerwijze ook in de Fransche landen, die het oppergezag der kroon alleen middellijk erkenden. Voor zoover wij een inzicht kunnen krijgen in het streven der groote leenmannen om het costumiere recht ook voor hunne gewesten door opteekening vast te leggen, zien wij, dat zij gedreven werden door dezelfde motieven, dat ook voor hun optreden beslissend is geweest datzelfde verlangen, een dam op te werpen tegen de groote kwaal van den tijd; de onzekerheid van de costumiere rechtsregelingen. Philips de Cloede zegt het ons in een ordonnance van het jaar 1459 , waarin de teboekstelling van de coutumes van Bourgondië wordt bevolen: "de ce que les coustumes... ont esté souventesfois proposées et prouvées en diverse et contraire manière, et que par ce diverses sentences et jugemens ont esté rendus, dont plusieurs grands et somptueux procès sont advenus et adviennent journallement" 5). Hetzelfde bewustzijn heeft de hertog Pierre de Bourbon die in 1493 maatregelen treft om tot de boekstaving van het costumiere recht van Bourbon en Auvergne te geraken: „mettre certeneté aux jugemens d'iceux, tant que faire se pourra, et oster toute matière de variation et contrariété, qui le temps passé se sont ensuivis, à cause de la diversité desdites coustumes" 6). Zoo streefde Marie d'Albret er naar, dat door de opteekening de contumes van het land van Nevers zouden "estre certaines" 7). Zoo geeft de prins-aartsbisschop van Kamerijk, Lodewijk van Berlaymont,

1) Eu 1579 C. G., IV, bl. 166; Orleans 1583 lierb.. aangeh.

2) Eu 1579 . hierb, aangeh

3) Chaulny 1609 C. G., IL, bl. 691.

4) Normandio 1599 C. G., IV, bl. 144.

5) C. G., Il, bl, 1193, vgl. ook bl, 1194 en C. G., II, bl. 1169.

c) $G, G$, IIJ, bl. 1208.

7) C. G., III, bl. 1166 (1534). 
aan als reden voor zijne bemoeiing met de opteekening van het recht (1574) "que les constumes de ceste nostre ville et pays de Cambresis, seroient peu certaines et arrestées" 1). Zoo brengen de hertogen van Lotharingen, bij hun optreden ten gunste van de vastlegging der coutumes in hunne landen, herhaaldelijk het motief der geschreven zekerheid, telkens voor de eene plaatselijke contume naar voren: „établissons loix certaines" 2), (St. Mihiel 1571), ,afin que la justice leur soit tant mieux et plus certainement administrée" 3) (Bar-le-Duc 1579), ,afin de rendre tant plus certaine à l'advenir lesdites coutumes" 4 ) (Bassigny 1580), terwijl in 1624 Karel III van Lotharingen zegt te hebben ,recognu.... l'ineommodité que nos sujets reçoivent par la diversité des coustumes" 5 ). Tusschen de twee genoemde hertogen in heeft geregeerd Hendrik van Lotharingen, die even het andere geluid doet hooren (1609): "y ordonner ce qu'il verroit estre juste et raisonnable" 6). Maar dat geluid klinkt maar even. De groote opteekening wordt in de Lotharingsche landen tot stand gebracht door hertog Karel II, die zijn standpunt met groote duidelijkheid formuleert: "lesquelles (coutumes) à ce moyen seroient demeurées confuses; et pour l'incertitude d'icelles, les parties plaidantes, ont les unes esté contrainctes de suivre les façons de foire d'autres provinces, ou bien de. prouver par tourbes" 7).

Na Hendrik IV verliest de teboekstelling der coutumes hare groote beteekenis voor het rechtsleven van Frankrijk. Niet dat het werk, met inbegrip van de herziening, voltooid was. Tot 1788 toe heeft men nog opteekeningen tot stand gebracht. Maar hare leidende rol voor de hervorming en de hernieuwing van het recht hebben zij verloren. De leiding wordt overgenomen door een andere beweging, die ons hieronder gaat bezighouden.

Zoo wordt in dit voor de geschiedenis van den Franschen stant zoo beslissende tijdsgewricht de eerste doelbewuste werkperiode van de Fransche codificatiebeweging afgesloten. $\mathrm{Zij}$ is wezenlijk geweest een streven naar opteekcning, zonder: noemenswaardigen wijzigingstoeleg, van het bestaande plaatselïjke en gewestelijke costumiere recht, van

1) C. G., II, bl, 281.

2) Karel II v. Loth. C. G., II, bl. 1058.

s) Dezelfde $C . G .$, II, bl. 1031 .

1) Een commissie, door Karel van Lotharingeu ingesteld, $C . G$., II, bl. 1150.

5) C. G., II, bl. 1073 .

) C. G., II, bl. 1090

г) C. G., Il, bl. 1058. 
als gewoonterecht geboren en roortbestaande rechtsregelingen. Hare rechtsgedachte was gericht op die rechtszekerheid, welke de duidelijke, in schrift gebrachte verzameling van het bestaande schijnt te beloven tegenover de twijfelachtige gelding van het mondeling uit een grijs verledem overgeleverde 1). De processen waren langzaan, ingewikkeld, kostbaar. Dat drukte als een zware last op het volk. Men procedeerde daarbï veelal zeer moeizaam over de vóorvrang: hoe luidt het gewoonterecht, waarop partijen zich gaan beroepen? En men hoopte met één slag het procesleven in gezonde banen te leiden door die voorvraag voor goed tot onbetwistbare oplossing te brengen. Dat moest door de opteekening van het gewoonterecht worden bereikt. Die eene gedachte bezielt de gansche beweging. Toen die gedachte verwezenlijkt was, kwam de bittere teleurstelling: de lange en kostbare processen bleven bij voortduring de kwaal van het Oude Regime, men moest nu ervaren, dat men met evenveel hardnekkigheid, als te voren over het bestaan van den rechtsregel, zou procedeeren over zijne toepassing. Men kwam toen tot de ontdekking, dat het onduidelijke recht niet de ecnige, wellicht niet de ergste kwaal was van den tijd. En. de codificatie, die altijd de volkeren door hare machtige belofte is blijven bekoren, gaat zoeken naar nieuwe banen. Maar alvorens wij deze opspeuren, vrangt iets anders onze aandacht.

III.

De practijk had de officiëele vastlegging niet afgewacht: twee en een halve eeuw vóór Karel VII de ordonnance van Montils-les-Tours uitvaardigde, hadden anderen met de opteekening van het recht reeds een aanvang gemaakt. Die opteekeningen, ondernomen door privaatpersonen, rechtsgeleerden uit de practijk, heeft voor de Fransehe rechtsgeschiedenis een ongemeene beteekenis gekregen, niet alleen - dat spreekt van zelf - als kenbron, voor ons, van het recht der XIII' en XIV* eeuw, maar ook voor het rechtsleven van dien tijd. Die beteekenis komt op drie wijzen tot uiting. Die rechtsboeken zijn geschreven als private verzamelingen, maar sommige hunner hebben in den loop der tijden erkenning vain overheidswege ontvangen, de meeste andere hebben het allengs tot een feitelijk annzien gebracht, die met half-officiëele erkenning stond. Zij zijn in de tweede plaats begonnen als verzame-

1) Het is dus nict juist, roor dit tijuperk de "uniformité des rêgles législatives" als "besoin général" naar voren te brengen. Aldus Picorr, II, bl. 55. 
lingen van gewestelijk, soms van plaatselijk recht, maar vóór het einde der XIIIe eeuw openbaart zich een streven naar generalisatie, naar samenvatting van het costumiere recht van een aanzienlijk deel van Noord- en Midden-Frankrijk. Zij zijn ten silotte opgevat als beschrijvingen vau het geldende recht, maar spoedig ontstaat de neiging tot wetenschappelijke, beginselvaste behandeling der stof. De twee laatstvermelde omstandigheden hebben van zelf geleid tot de versmelting van het uationale costumiere recht, met het kerkeijk en Romein.ch recht: de nieuwe en zich wijzigende behoefte des tijds toch werden in het canonieke en vooral in het Romeinsche kleed gestoken. Zoo bebben de private verzamelingen gebracht een begin van rechtsgeneralisatic, een begin van rechtswetenschap en een begin van uitbouw van het nationale recht. Daarin schuilen even zoovele wordende behoeften van het rechtsleven der eeuw. En de zucht, die kiemende en tot bewustheid komende beboeften to bevredigen, heeft gewerkt als een stille drijfkracht voor die opteekeningen. Intusschen hebben wij de rechtsboeken hier alleen te beschouwen in hun verband met de codificatiegedachte. Dat verband bestant, onmiddellijk omdat door de officiëele of quasi-officiëele erkenning de rechtsboeken tot samenvattingen van normen zijn geworden, die roor heele streken hebben gegolden; middellijk omdat van hen èn op de redactie der coutumes èn op het latere streven naar eenbeid invloed is uitgegaan ${ }^{1}$ ). Wij krijgen hier dan ouder het oog te zien de vrang: waarom verwaehtten van de massale opteekening de opteekenaren het heil of, anders gezegd, welke specifieke verwachting koesterden zij juist van de samenvattende rechtsbeschrijuing?

De gegevens voor dit onderzoek zijn dun gezaaid. De meeste dier rechtsboeken toch laten ons in het duister omtrent de beweegredenen der bewerkers. Veel kumnen wij enkel gissen op grond van wat zij doen, zonder dat wij met zekerheid weten op grond van wat zij ons uitdrukkelijk zeggen. Soms is dit echter anders.

Het ligt roor de hand, dat de kwaal, welke wij hebben leeren kennen als de groote plaag ran het rechtsleven tegen den uitgang der Middeleeuwen, ook hier een rol van beteekenis moet spelen. Ook de mannen der practijk, die naar de pen grepen, hebben dit vóór alles gedaan om de rechtsbezorging, welke hun an het hart lag, te verlossen van de onzekerheid omtrent het bestann der rechtsregelingen

1) Overdreven is op dit stuk de voorstelling van Dupin et Labouraye, Imstitutes coufumières d'Antoine Loisel, Paris 1816, I, bl. XXII. 
- yelve. De Tres Ancienne Contume de Bretagne zegt het in hare gemoedelijke taal: „pluseurs seigneurs et pluseurs juges qui avoint justice à gouverner et ne la gouvernoint pas touz generalment selon les coutumes qui sont establies en Bretaigne, et selon que droit et justice doivent estre faictes, pour ce que'ils ne les savoint". Zoo gebeurt het vaak (plusieurs fois avenoit), dat de rechters „bailioint le tort a celui qui devroit avoir le droit et "le droit à ceul qui devroit avoir le tort" en wel sommigen "par soustenance", maar anderen omdat zij het recht niet kennen, "par non savance". Dic wantoestand heeft de bewerkers tot schrijyven aangezet: „donc nous avons commancé à escripre" 1). Even sprekend wordt deze drijfveer voor de opteekening vermeld in een der rechtsboeken van het overzeesche Frankrijk der XIIIe eeuw, in de Clef des Assises de la Haute Cour. Het komt den schrijver geboden voor, „que le chief seignor dou royaume de Jerusalem et les barons et les autres riches homes qui ont cours et coins et justice, sachent les assises et les usages doudit royaume" en nque leurs houmes qui doivent estre jurés 2) de leur cors sachent bien droitement jugier jugemens que il devront faire selone celles assises et ceans usages". En daarom: „ais je coumencé ce livre" 3). Die ontrotendheid van de tot de rechtspraak geroepenen vindt hare. oorzask in de onzekerheid van het niet opgeteekende costumiere recht. In sombere kleuren schildert PIERRE DF Fontaines die verwarde onzekerheid voor het land van Vermandois, ann welks recht hij door zijne beschrijuing meerdere vastheid wil geven: „les ancienes costumes que li preudome ģà en arière soloient tenir et user, sont molt anéanties et presque totes faillies... et si que li païs est à bien près sanz costume". De rechtspraak komt dan op zeer lossen grondslag te staan: "Si que presque toz va par aris eomun de IIII ou de III, sans exemplaire de costume qu'il tiengnent. Et de ces avis avient-il molt sovent que tex pert qui gaaigner devroit" 4). Hieraan voegt Pierre de Fontaines niet met ronde woorden toe, dat die wantoestand hem tot schrijven heeft aangezet. Doch dit is tusschen de regels door met voldoende duidelijkheid te lezen.

Beaumanork staat het nut der rechtsopteekening helder voor den geest: "il m'est avis, et as autres aussi, que tens coustumes qui maintenant sont usees, sont bonnes et pourfitalles a eserire et a enregistrer, si qu'eles soient maintenues sans changier des ore en avant, que, par

1) Irès anc. cout. de Brelagne, prologue, uitg. Plantol, Rennes 1896, bl. 52.

2) De tekst leest njugés", dat geen zin geeft. Ik waag de verbetering njurés".

3) Prologue, uitg. Beugnot, Paris 1841, I, bl. 557.

1) The Conseil, uitg. Marnier, Paris 1846, I, 3. 
les mémoires qui sont escoulourjans et par les vies as gens qui sont courtes, ce qui n'est escrit est tost oublié". En hij verwacht daarvan goede gevolgen voor de rechtspraak: "se Dieu plest, par cest livre pourra il estre enseignié comment il (de graaf van Clermont) devera garder et fere garder les coustumes de sa terre de la conteé de Clermont". Maar de scherpe kop onder de juristen van het Middeleeuwsche Frankrijk dacht dieper door. Wat nog geen ander was opgevallen, de bonte verscheidenheid van het costumiere recht binnen den éénen nationalen kring, heeft hem als een $\mathrm{k}$ wasl var het rechtsleven getroffen: „les coustumes sont si diverses, que l'en ne pourroit pas trouser ou roiaume de France deus chasteleries qui de tous cas usassent d'une meisme coustume". En hij zal, nu hij de wonde kent, doelbewust het heelmiddel annenden: ${ }_{n}$ nos entendons a confermer... l'autre partie (de cest livre), par le droit qui est communs a tous ou roiaume de France" 1). Hier klinkt, midden in de XIIIe eeuw, voor het eerst een motief voor samenvattende rechtsopteekening ${ }^{2}$ ), dat spoedig een nieuw ideaal zal stellen aan het streven naar codificatie: de eenheid van het nationale recht.

Die eenheidsgedachte is in wording. Zij kont tegen het einde der XIVe eeuw tot practische uiting in de twee rechtsboeken, die de reeks dezer verzamelingen besluiten, in den Grand Contumier de France en in de Somme rural. Noch Jaques d'Abigiges, noch Jehan Boutillier hebben ons hun programma ontwikkeld. De Somme rural zwijgt geheel over des schrijvers bedoelingen en wat de Grand Contumier daarvan ontsluiert is niet veel meer dan de nitgesproken persoonlijke voldoening van den tot rijpheid gekomen man, die in nuttigen arbeid de zelfvergeving zoekt voor de lichtrinnige levensopvatting rijuer jeugd. De diepere gedachte van het werk wordt niet omschreven. Maar met

1) Coutumes de Beauvaisis, uitg. Salows, Paris 1899 , urs. 7, 3, 6.

2) Ook de veelbesproken voorrede van de Kkablissements de St. Lomis wekt den schijn, alsof eenheid van wetgeving voor het geheele land binnen den gezichtskring des konings zon hebben gelegen (uitg. Viot, ET, Paris 1881, 11, bl. 473-47s). Maar de onderzoekingen van VıL, La hebben den Iraad, die het stuk aan de ver zameling zelve heette te binden, doargesncden. De proloog is niet afhomstig van den $B$. Lodewijk, en maakt geen reel uit ran den oorspronkelịken tekst der compilatie

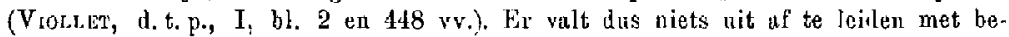
trekking noch tot het doorzicht vas den vorst noch tot den opzet van den verzamelaar. Wel blịkt er uit, dat het denkbeeld der nationale rechtseenheid bestond, zij het dan slechts bij den bezorger eener latere nitgave. In liens brein is lat echter niet anders dan een vaag denkbeeld, buiten verband met le opteekening. 
de daad wordt het streven verwezenlijkt: te geraken tot eenheidsrecht voor het geheele koninkrijk, boven de plaatselijke verwarring en de nationale verscheidenheid vit.

In de XVIe eenw komt het denkbeeld krachtig naar voren. Het draagt en bexielt het levenswork der groote rechtsgeleerde leiders.: Imbert, Dumoulin, Coquille, Loiski. Ook zij doen veel voor de eenheid en spreken er - behalve Dumoutin - weinig over. Maar genoeg om ous een inzicht te geven in hun bewast streven. IMBERT schrijft zijn programma neer in den titel van zijn hoofdwerk: Institutiones forenses Galliae pene tolius 1 ). GuY CoQuILLE had in den aanvang geen oog voor de eenheid ${ }^{2}$ ), doeh later bewerkte hij de Institutions an Droict des François, „où le Droict universel de nostre Royaume soit méthodiquement estendu et expliqué" "3). De Institutes coutumières van Lorses hebben dezelfde eenheidsstrekking. Lorser is zich ten volle bewust van de roeping zijner onderneming: „les-provinces, duchés, comtés et seigneuries do ce royaume régies et gouvernées sous diver'ses coutumes, se sont avec le temps rangées sous l'obéissance- d'un seul roy, et quasi de sa seule et unique monnoie: ainsi enfin se pourraientelles réduire à la conformité, raison et équité d'une seule loi" 4).

Verreweg de machtigste invloed in de richting is uitgegaan van Dumoduin. Zonder zijne opwekking zou vermoedelijk de arbeid van Guy Coquilue en Lorser niet denkbaar zijn geweest. Dumoulin is de onvermoeibare en onvermocide strijder geweest voor de volle verwezenlijking van de eenheidsgedachte in het koninkrijk Frankrijk. Heel de kracht zijner geweldige persoonlijkheid beeft hij ingezet voor de eenhcid van land, volk en staat. Dit grootsche ideaal verbindt zijne werken over het leenstelsel, over het koningschap, over het burgerlijk recht. Op dien grondslag staat ziju commentaar op de coutume van Parijs, zijn later de aanteekeningen op bijna alle coutumes van het rijk nitgewerkt: het plaatselijk en gewestelijk recht

1) Vgl. ook den annhef der Fransche bewerking: "Comme j'aye deliberé de traicter tout-l'ordre et procedare des jugrements de la Gaule coustumière." Practique civile et criminalle, uitg. GeNeve, 1625 , I, I. 1.

2) In de Questions, responses et méditations staat hij nog op het gewestelijk standpunt: "chacune province a ses moeurs et humeurs diverses; et partant les loix.... doivent-elles estre faites selon le goust et sens de chacun peuple." Question Ie. Oeuvres, Paris 1666 , II, bl. 158-154.

3) Voorrede, Oeuvres, I, bl. e.[V. Vgl. ook VıoLurr, Histoire du droit civil français, Paris 1905, bl. 230.

-) Uitg. Dupin et Laboljlaye, Paris 1846, I, bl. XXXVI. 
moet worden getoetst an de coutume van Parijs, die van onbetwistbaar beter gehalte was dan hare zusterregelingen en die bovendien door de leidende rol, welke de boofdstad vervulde, het natuurlijk middelpunt der toekomstige rechtsontwikkeling moest worden 1). Maar de groote steot is uitgegaan van de beroemde Oratio de concordia et unione consuetudinum Franciae ${ }^{2}$ ). In haren ongemeen opwekkenden betoogtrant, in haren hartstochtelijken, ofsehoon gezwollen stijl, in hare gemakkelijk overzienbare beknoptheid, en door bewerking in de volkstaal voor ieder toegankelijk gemaakte leesbaarheid blijft de Oratio, ondanks hare gebreken, een zeer merkwaardig doeument in de gesehiedenis der codificatie. De groeiende tijdsbehoefte had nu hare literaire formuleering, de beweging haar duidelijk omschreven programma ontvangen: ,consuetudinum in brevem unam, clarissimam et aequissimam consonantiam reductio." Daartoe was noodig ,, brevissimus, candidissimus, expeditissimus et absolutissimus libellus.... juri communi et aequitati naturali consonantissimus", met andere woorden: een wetboek met al zijn, uitnemende hoedanigheden.

Toch maant juist de uiterlijke schittering van Duxodurs's ingrijpen tot voorzichtigheid bij de beoordeeling van de plaats, welke dit ingrijpen in de codificatiebeweging toekomt. Dumoulis trekt geweldig te velde tegen de rampzalige rechtsversnippering der coutumes "diffusissimae et ineptissime saepe variantes huius regni consuetudines", „,multa diffusissima plurium variantissimarum, contrariarum (bovendien:) obseurarum, iniquarum, ineptarum, mancarum consuetudinum", brengt met reel virtuositeit de kwaal naar voren, die in Frankrijk den groei van een gezond rechtsleven belemmerde, de verwarring en onzekerheid : "nihil periculosius, nihil exitiabilius earum (= legum) confusione et incertitudine.... Judex vero neque bonos tneri, neque malos coercere prae juris confusione et incertitudine possit", ,quae varietas ut plurimum omni ratione et utilitate caret". Maar verwarring en onzekerbeid kunnen vele oorzaken hebben. En voor deze verschillende oorzakelijkheid heeft Duxoulis te weinig oog. Vóór de teboekstelling der coutumes betrof de onzekerheid het bestaan der rechtsnormen zelve. Dat laat ook de Oratio wel uitkomen ${ }^{3}$ ), maar ook die onzekerheid, ,ante conscriptas

1) Hierover Aubérin, Reoue critique de législ el de jurispr. IV, 1854, bl. 277 v.v.

3) Opera, Parisiis 1681, II, bl. 690-692. Voor al de aanhalingen wordt daarnaar vorwezen; nadere anduiding komt onnoodig voor.

3) "Contraria vel diversa consuetudine non ostensa, sed in facto probando posita" of nog duidelijker: "Obseurior et incertior erat n o ti ti a consuetudinum, quarum nalla nisi per confusa testimonia habebatur probatio." 
conauetudines" duidt zij weer aan met het ééne begrip ,illa miserrima confusio et incertitudo juris." Gevaarlijker dan voor het verleden wordt die algemeene aanduiding voor den tijd, warin de schrijver leeft. Want ook toen kwam, zooals wij spoedig nader zien zullen, de verwarring uit twee verschillende hoeken. Behalve de veelheid der rechtsregelingen in het eene land, hinderde de verscheidenheid der rechtshronnen ter plaatse. Voor dit laatste heeft Domoours geen aandacht.

Hij geeft wol hoog op van de ,contrariae... in eadem scriptura et consuetudine", van de "variae et diversae de eadem re" van de "Inultae abscurae et ancipites, et distorrae", van de „ineptac et supervacuae" en "defectivae", later nog eens van "tot articuli controversi indecisi,... tot contrarii, ancipites, et iniqui inemendati". Doch daarmede worden, niet zonder orerdrij ving, alleen inwendige fouten van de coutumes aangewezen. Zoo wordt de schijn gewekt alsof de wensch der nationale eenheid, daarnaast de teleurstelling over de gebrekkige redactie der coutumes veel meer op den voorgrond stonden dan het verlangen naar eenheid van recht in den kleinen plaatselijken kring. Zoo voelde het volk niet. De veelheid der coutumes had wel de aandacht gewekt, zij had zelfs BeaumanoIr al gehinderd, maar zij hinderde toch veel meer de vooruitziende geesten dan het volk. Geniale en op groote herrorming zinnende mannen ala Beaumanorr en Dumoulis kunnen gevaarlijk worden als kenbron voor het streven en denken van humnen tijd. Voor Dumouris komt nog daarbij, dat hij de gandche codificatie ondergeschikt maakt aan een hooger doel, dat zï de eenheid van Frankrijk dienen moet. Dit wordt ook in de Oratio allerminst verheeld '). De eenheid van wetgeving makkt deel uit van de eenheid van stant en volk. Zoo wordt Dumoubis van zelf gedreven in een denkrichting, die de uitsluitende aandacht samentrekt op de unificatie van het recht en, als oorzaak van den wantoestand, op de veelheid der rechtsregelingën, tegen welke de unificatie verbetering brengen moet. De opwekking, welke van Dumoulis is uitgegaan - dat ligt voor de hand - heeft hare vruchten gedragen en mede leiding gegeven aan het streven der nnaste toekomst. Maar de tijdgenooten zelf voelden het vraagstuk niet zooals hij het zag. Wanneer de XVIe eeuw al begint te vermoeden, dat de in hoofdzaak voltooide opteekening van het gewestelijk recht, met de overigens verre van afdoende zekerheid omtrent het bestaan der normen, niet de verlossende uitkomst voor het rechtsleven zou brengen en al luider en luider gaat roepen om algemeene codificatie,

1) Zie hieronder bl. 227 . 
dan wordt daarmede niet in de eerste plats beoogd, aan de nationale verscheidenheid een einde te maken.

Maar het streven naar eenheid bestond, zij het als mode-werkende, geenszins als alleen-werkende of zelfs vooral-werkende factor voor de codificatie. Dit streven is opgewekt en bevorderd door de rechtsgeleerden sedert de XIIIe, vooral in de XVIe eeuw. En zij hebben, sinds BeadmanorR, door hunne samenvattende bewerkingen vall het recht van geheel Frankrijk of van het costumiere Frankrijk, ook waarlijk reeds half-codificatoiren en voorbereidenden codificatoiren arbeid verricht. Rechtstreeksch verband met de codificatie is wellicht in het geheel niet waarneembarr. Maar. het middellijk verband is onloochenbaar: het streven uaar de massale samenvatting van het recht voor heel het land is door hun werk levendig geworden. En dit streven zal allengs door de codificatiepolitiek worden overgenomen en tot het hare worden gemaakt. Het verlangen naar samentrekking van het gansche nationale recht in wetboeken door den wetgever is sterk aangewakkerd door de maseale samentrekking van het nationale recht in samenvattende bewerkingen door de rechtageleerde schrijvers.

IV.

Een nieuwe tijd breekt nu aan voos de codificatiebeweging in de tweede helft der XVIe eeuw. Tot nog toe was de vastlegging door de overheid uitsluitend gericht geweest op de teboekstelling van gewestelijk en plaatselijk recht. Er leefde anderzijds een streven naar samenvatting van algemeene nationale rechtsnormen, dat wij hebben leeren kennen. Maar dit streven ging schuil in den arbeid van privaatpersonen, mannen vau praktijk en wetenschap.

Uit de samenvloeiing van die twee stroomingen wordt nu het nieuwe verlangen geboren: de codificatie door de overheid voor het gansche land, de wettelijke vastlegging van het nationale recht als eenheid en algemeenheid gezien. Wat vroeger alleen eea postulaat was geweest van vooruitziende geesten, wordt nu langzamerhand de gemeene wensch der natie. De tijd gaat de voorloopers inbalen. En wat het volk begon te verlangen, daaraan gaven de leiders des volks richting en stuur. De tot deskundige voorlichting geroepenen bleven niet achter. Zoo wordt de nieuwe codificatiebeweging ingezet, door den rollswensch gedragen, door de juristen angewakkerd, door de regeerders geleid. Maar die samenwerking wordt in hare harmonie weldra verstoord: het absolutisme breekt door met ajne dubbele neiging, aan de volksstem 
het medezeggenschap te ontnemen en tegelijkertijd het aandeel der geleerden aan den opbouw van nationaal werk in de bedding van de overheidsbemoeiing te lokken en vast te leggen rondom de Kroon. Onder het Ancien Régime staat dan het absolute centrale gezag in het middelpunt ook van deze beweging.

Voor deze periode krijgen wij nu de vraag onder het oog te zien: welke zijn van dit pogen de stuwkrachten, welke is van dit nieuwe codificatie-streven de rechtsgedachte? Langzamerhand wordt de zwangerschap voorbereid, die de wetboeken zal voortbrengen, waaronder ons geslacht, in Frankrijk en daarbuiten, nog altijd leeft. Daarmede stijgt de belangrijkheid der vraag en worden bijzondere omzichtigheid en nauwgezetheid van onderzoek geboden.

Men is gewoon de rechtsgedachte der codificatie te ontraadselen met twee schijnbar eenvoudige sleutelwoorden: rechtseenheid en rechtszekerheid. Zoo eenvoudig is echter de oplossing niet. Nader onderzoek zal ons leeren, dat de codificatie wordt gedragen door drie dooreengestrengelde rechtsgedachten. Zij heeft willen brengen en inderdaad gebracht de verwezenlijking van drie verknoehte, in den loop der tijden algemeen en sterk geworden eischen des tijds, van drie verknochte beden des volks: rechtsveiligheid, rechtsvereenvoudiging, rechtseenvormigheid. Rechtsveiligheid tegenover gezagsmisbruik en willekeur in de gezagsuitoefening der overheid, de koninklijke en de rechterlijke. Rechtsvereenvoudiging, rechtsklaarheid, rechtsontwarring tegenover de rechtsversnippering, de verwarrende veelheid der rëchtsbronnen binnen denzelfden plaatselijken rechtskring. Rechtseenvormigheid, rechtsgeneralisatie, rechtsnationaliseering tegenover het rechtsparticularisme, tegenover de verscheidenheid van regeling in de verschillende deelen van dezelfde staatkundige en ethnologische eenheid. Het is noodig, die drie gedachten, dat drievoudig streven te onderscheiden en niet de drie gedachten verwarrend samen te persen in deze twee andere: rechtszekerheid en rechtseenheid. Rechtsveiligheid beteekent rechtszekerheid in dezen éénen zin van beveiliging, zekerheidsverschaffing tegenover de overheidsmachten. Maar rechtszekerheid in dezen anderen zin van "weten waar men aan toe is", zekerheid, die geeft een eenvoudige en gemakkelijk te overziene rechtsregeling, valt ton deele samen met rechtsrereenvoudiging, die dan tegelijkertijd, daardoor, streeft naar rechtseenheid in dezen éénen zin van plaatselijike eenheid der rechtsregelingen. Doch daarnaast staat cen ander, derde, doel: rechtseenheid in dezen anderen zin van nationale eenheid der rechtsregeling, welke specifiek wordt aangeduid als rechtseen 
drie gedachten, drie bewuste stroomingen", die genezing moeten brengen voor drie diepgevoelde $k$ walen van het rechtsleven: de onveiligheid 'tegenover de overheid, de hinderijke veelheid der bronnen binnen denzelfden plaatselijken rechtskring, de belemmerende rechtsverscheidenheid binuen den grooten nationalen kring. De onderscheiding belet natuurlijk niet de verknochtheid: zooals de kwalen onderling samenhangen en op elkander inwerken, zoo ook de aanwending der geneesmiddelen. Zooals b.v. de onveiligheid wordt in de hand gewerkt door de onklare veelheid der regelingen, zoo zal de vereenvoudiging, met de klaarheid, ook bevordering der veiligheid brengen.

Op het stuk van privaatrecht treedt, scherp geteekend, op den voorgrond het streven naar' rechtsvereenvoudiging en rechtseenvormigheid. Het rechtsleven bleef gebukt gaan onder twee lasten: de veelheid der rechtsbronnen binnen denzelfden kring en de ongelijkheid der regelingen in hetzelfde land, de platatselijke veelheid en de nationale verseheidenheid. Het recht lag opgestapeld en dooreengemengd in gewestelijke, daarnaast plaatselijke contumes, koninklijke ordonnanties, een verwarde massa $\operatorname{van}$ oidonnances in engeren zin, édits, déclarations en lettrespatentes, edicten der souvercine parlementen, ${ }^{\text {statits, }}$ reglemens, styls ot usages", het geheel sterk vermengd met canonieke en Romeinsche bijmengselen. En veel daarvan verschilde bovendien van plaats tot plaats, van gewest tot gewest. Zoo was de dubbele wantoestand, waartegen het codificatie-streven der XVIe eeuw den strijd gaat ondernemen Duidelijk zien wij nu twee lijnen zich aftcokenen: men vraggt om codificatie ter wille van de rechtseenvormigheid en ter wille van de rechtsvereenvoudiging. Het eerste motief stant op den voorgrond bij de juristen, bij het volk echter het andere. Voorloopig knelt de locale rechtsverwarring veel meer dan de nationale verscheidenheid. En dit is zeer begrijpelijk. In een tijd, waarin de plaatselijke handel en de plaatselijke familiebetrekkingen nog ver overheerschend waren, werd het als meer hinderlijk gevoeld, dat de kooper en de verkooper ter zelfde plaatse in onzekerheid verkeerden ontrent de rechtsregeling van den koop, dan dat de kooper te Rouen en de verkooper te Parijs moeilijkheden ondervonden van de onderlinge afwijking der Parijsche en Normandische bepalingen op dat stuk.

De stem des volks doet voor het eerst een geluid van dezen klank hooren bij gelegenheid van de vergadering der Etats-Grénéraux te Orleans in 1560 gehouden. De Staten van Orleans, gelijk die van Blois, verlangden vóór alles nog de voortzetting, en de laatste ook de her- 
ziening van de opteekening der coutumes $\left.{ }^{3}\right)$. Dat was nog het oude standpunt. Het nieuwe komt echter tevens naar voren. De adel en de derde stand knesteren groote verwachtingen van de codificatie. Doch slechts even, en dan nog bescheiden, alleen voor het procesrecht, klinkt daarbij het motief der rechtseenvormigheid. De derde stand vragt dat "tous les styles fussent réduits en une forme, tant en première qu'en seconde instance" 2). Overigens is er maar één roep, om rechtsvereenvoudiging. Niemand denkt zelfs aan de codificatie van het costumiere recht, die toch de groote brengster der eenheid zou rijn. Men verlangt integendeel de samentrekking der ordonnances, die toch al nationaal eenheidsrecht zijn, welk eenheidsrecht echter lijdt aản onduidelijkheid en verwarring. Naar de formulecring doon den derden stand: dat er ${ }_{n}$ fut fait recueil de ce qui devoit être dorénavant gardé et observé entre les sujets,

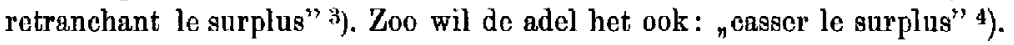
Dat „surplus" stichtte de verwarring. En daartegenover hoopte men tot klaarheid te zien brengen de duistere vragen , du droit escript et des coustumes affin de remettre le tout en langage clair" 5 ). Voor de gewesten van het ngesehreven recht" wordt dezelfde wensch geuit: samengebracht moeten worden "les lois nécessaires et les mettre en françois, en termes certains et non ambigus" $\left.{ }^{6}\right)$. De partijen moeten weten, waaraan zij zich te houden hebben, in zoo de twistgedingen voorkomen: pour que les parties pussent si bien entendre le mérite de toutes causes, que d'eux-mêmes ils en soient les premiers juges, et qu'ils fassent raison les uns aux autres sans procès" 7 ). Het is uit den hier weergegeven inhoud der doléances gemakkelijk te zien, dat men vóor al het andere smachtte naar de verlossing van de kwaal der rechtsverwarring ${ }^{8}$ ).

Te Blois, in 1576, stelde men hoogere eischen. Ditmaal drongen geestelijkheid en derde stand aan op een algemeene codificatie, die

1) Zie hier boven bl, $19 \dot{8}$ en 199.

2) Picot, II, bl 302.

3) Picor, II, bl. 335.

1) T. z. p.

5) Noblesse 56, bij Picor, II, bl. 335 .

6) Noblesse, bl. 201, art. 3, bij Prcor, II, bl. 334.

7) T. z. p.

8) Zoo anchtte ook het bijzondere enhier van den adel van Paitou, Noblesse bl. 201, art. 4, bij Picor, II, bl. '334 n. 2: "qu'il y a beaucoup de procès et disputes pour les interprétations des édits et ordonnances royaux", dit is in het eenheidsrecht, terwül van de coutumes niet gerept wordt. Doch men vroeg hier, ter verbetering, niet om codificatie. 
zoowel de ordonnances als de coutumes en de edicten der parlementen in suo volume ot cahier" 1) zou omsluiten. Maar alleen "celles qui se devront garder et qui se tronveront utiles et nécessaires en ce royaume, afin d'abroger toutes les autres" 2 ). Dat wijst dadelijk op het verlangen naar klaarheid, hetwelk nog duidolijker wordt uitgesproken in deze klacht vau den derden stand, over „beaucoup d'édits publiés par les cours souveraines, avec certaines charges et modifications incertaines, que l'on dit seulement être contenues ès registres sans savoir autrement ce que c'est"' 3). Maar vooral in de klacht der geestelijkbeid vinden wij weer de oude wondeplek, wanneer daarin de drijfveer van den wenseh naar codificatie met ronde woorden wordt neergelegd: „ponr éviter la confusion de la multiplicité des lois" 4). Het antwoord des konings is geheel van hetzalfde inzicht doordrongen. Daarin wordt in het vooruitzicht gesteld, dat hij althans de op̧donnances zal doen „recueillir et arrester.... réduire par ordre en un volume celles qui se tronveront utiles et nécessaires". Hendrik III heeft die belofte tot op zekere hoogte vervuld. Bussson bracht den Code Henui III tot stand, warmede ten minste iets van het beoogde doel was bereikt. De arbeid van Brisson verspreidt, voorzoover ik heb kunnon nagaan, zelf geei licht over de gedachte, die bij zijn opzet heeft voorgezeten. Maar Charondas doet ons daaromtrent, in zijne bewerking van den Code Henri III, een kostbare mededeeling, die opnieuw er op wijst, dat de tijdgeest codificeerde on het euvel der rechtsverwarring te bestrijden : et contrariété des loix n'apporte que confusion au droict et à la justice.... (en voortgaande in dezen gedkehtengang:) Pour ce royaume, Mongieur Brisson.... avoit du vivant du feu Roy Henry III .... et par le commandement de sa Maiesté, recueilly les ordonnances...."5). Het streven naar nationale eenheid van recht speelt bij dit alles geen rol. Zoo weinig denkt de koning bij zijne torzegging daaraan, dat hij tevens aankondigt, zijne aandacht te zullen wijden aan de taak, te doen ${ }_{n}$ rédiger, réformer et éclaircir au mieux qu'il sera possible les constitutions particulières et locales de chacune province" "6).

De Code Menri III had algemeene teleurstelling gewekt. Het was een verzameling van ordonnances geworden, niet volledig en niet met kracht van

\footnotetext{
1) Clergé 281 en Tiers 200, bü Picnt, III, bl. 269.

2) Clergé t. a. p.

3) Tiers t. a. p.

4) Clergé t. a. p.

5) Epistre au Roy, Code Henri III, nitg. Paris 1609, bl. a III.

0) Ordonnance Paris mai 1579, art. 207, bjj Isamblert, XIV, bl. 430.
} 
wet voorzien. De Code Henri IV is niets anders dan een misleidende bertaming voor de vertaling van een bewerking in het Latijn van het gerioipieërde Romeinsche recht, die niets gemeen heeft met den koning-wetgever Hendrik IV en niets met een codificatie van het Fransche recht, dan dat het „droit civil iadis descrit, et à nous délaissé confusement par l'empereur Juatinian" heet te zijn „maintenant reduit et composé en bon et certain ordre, avee le droit eivil de la Franee" 1). Maar de mooie titel had misleidend gewerkt en de teleurstelling vergroot. Die gevoelens komen tot niting in de Statenvergadering van Parijs, in 1614, waar de volkswensch bij herhaling wordt neergelegd in de algemecne en bijzondere cahiers: codificatie door den wetgever. En de beweegredenen van dit verlangen? PICOT geeft haar weer met deze woorden: "Le peuple était convaincu, non sans raison, que l'obscurité et l'incertitude des lois multipliaient les contestations" 2). Altijd weer hetzelfde geluid: Het volk snakt naar rechtsontwarring. Van rechtseenvormigheid wordt al dien tijd nawwelijks gerept.

Wel speelt eenmaal het derde codificatie-motief, het motief der rechtsveiligheid door. En wel te Orleans. De derde stand verwacht van de gevraagde codificatie ook dit: „que par ce moyen ou coupit à toute ... malice... des ministres de la justice" ${ }^{3}$ ). Te Blois en Parjjis wordt die klank niet meer vernomen. Wel wordt beide malen de cisch gesteld, doch buiten verband met de codificatie ${ }^{4}$ ). Het volk voelde wel voor rechtsveiligheid, mar het begreep nog weinig, dat de samentrekking van het recht ook daqrin verbetering zou brengen. Voor de

1) Zoo het titelblad der Fransche bowerking, die hiar veel nitvoeriger is dan de Latijnsche tekst. Zij is van de hand van den schrijver Thomas Cormer zelf, verschenen te Rouen 1615. De oorspronkelijke uitgave is van 1602, zonder plaatsaajduiding (apud Chover). Haar titel rerraad beter den inhoud: Henrici IIII ehristiznissime el cayustissimi Galliarun Navarrague regis Codex iuris civilis Romani. Een bÿwerking van den Code Henri III door Cilnaondas wns ook bestemd den naan Henri IV te vaeren (Epistre au Roy van Chanowess, afgedrukt vóór de latere uitgaven van den Code Henri IIJ, zoo Paris 1609, bl. a IlJ). De Code Louis XIII, (wel te onderscheiden van den Code Marichac of Mrchau onder Lodewijk XIII), is een verzameling van ordonnanees in denzelfden geest. De Codes Louis of Lou is $\mathrm{XIV}$ en Louis XV zija niets anders dan samenbundelende uitgaven van een des! der ordonnances dezer koningen. Zij hebben met codificatie in het geheel nie's nitstaande.

3) Picor, V, bl. 19. Prcot geeft ditmaal niet den telst der dolíances, doch alleen de samenvatting van den inhoud.

3) PIcor, II, bl. 335.

*) Picot, III, bl. 270 en V, bl. 20. 
nationale rechtseenvormigheid had het nog nagenoeg geen oog. De bijna uitsluitende aandacht is geconcentreerd op dit eene: rechtsvereenvoudiging.

\section{$\mathrm{V}$.}

Na 1614 wordt de stem des volks niet meer vernomen. Richelieu riep de standen niet meer samen om te luisteren naar wat er wrokte en leefde in de harten der onderdanen. Zoo is het gebleven tot op den vooravond der Revolutie. Er zijn dus geen doléances meer, die ons tot kenbron strekken van de nooden des lands. Wij zijn voor het tijdperk van het wordend en geworden absolutisme aangewezen op de geschriften der rechtsgeleerden en bovenal op de uitingen van den koning-wetgever en zijne medewerkende omgeving, wanneer wij willen beluisteren wat het Ancien Rógime van de codificatie verwachtte.

Richelieu en Mazarin hebben zich niet met het vraagstuk beziggehouden. Maar de scherpe aandacht wordt daarop samengetrokken sedert Lodewijk XIV de tengels van liet bewind zelf in handen heeft genomen. Van dat oogenblik af heeft het Ancien Régime geleefd in de hoop op de totstandkoming der algemeene codificatie van het privaatrecht, het strafrecht en het procesrecht. Die hoop is door Lodewijk XIV inderdaad verwezenlijkt roor het handelsrecht en het procesrecht. Aan dien arbeid heeft de rechtsgeleerde generatie van 1661 af gedurende meer dan twintig jaren hare goede krachten besteed. Aanvankelijk zonder onderlinge samenwerking: Pussort, Auzaner, Lamolgnon, SÉGUIER, zij hadden allen eigen denkbeelden en waren allen bevangen in eigen plannen. Het is ComBERT gelukt, de samenwerking tot stand te brengen en zoo de onderneming te maken tot cen nationale. De groote ordonnances van Lodewijk XIV, in warheid even zoovele wetboeken, zijn daarvan de vrucht geworden.

De leidende gedachte dier beweging is met voldoende zekerheid waar to nemen. Hen wil de codificatie om de rechtsvereenvoudiging en om de rechtseenvormigheid.

AUZANET wordt vooral getroffen door de rechtsverwarring: "Il y a peu de coutumes générales daus lesquelles il n'y ait des usages locaux; et.... on a recours au droit romain; et en d'antres cndroits, on considère les coutumes voisines. Et ce qui est encore plus important, e'est que, dans les provinces régies par le droit écrit, il y a plusieurs questions.... lesquelles se jugent différemment dans les mêmes provinces: Et le mal a passé jusqu'à ce point que, dans un même parle- 
ment, plusieurs maximes ont changé deux ou trois fois depuis trentes ans, et encore à présent elles se jugent différemment en diverses chambres d'un même parlement:" 1). Het euvel is hier gezien als een algemeene verwarring, maar de verwarring binnen den kleinen rechtskring sehrijnt het meest. Haar moet de codificatie in de allereerste plaats verhelpen. Zelfs ontraadt Auzaner nog de eenheid voor het gansehe land. Ziju herrormingsplan reikt niet verder dan „chacus bailliage et province" 2).

Lamoiganon deinsde niet terug voor den eisch der eenheid voor " tout notre royaume" 3 ). Vooral de Vie de $M$. le premier président de Lamoignon, bewerkt naar gegevens uit zijn tijd en familicpapieren, geeft ons, meer nog dan zịn eigen geschriften, een inzicht in de breedheid zijner opvatting: ${ }_{n}$ il est certain que $M$. le premier président s'étoit fait une idés plus grande et plus noble de la réformation de la justice; il vouloit que Louis XIV.... ê̂t la gloire de donner à sa nation une législation complette.... C'est ee voeu que M. de Lamorason cherchoit i remplir; e'étoit un code général et uniforme qu'il vouloit former." En het doel dat daarmede moest worden bereikt? "C'est cette multiplicití de loix contraires,... c'est cette diversité, ce combat de jurisprudence dans les différens tribunanx qu'il vouloit faire disparaître; il vouloi: en faire une loi générale du royaume" 4 ).

In CoLBkR'r's voorstelling zijn de twee motieven voor codificatie ver.knocht. Ook hij wil, door de vastlegging in wetboeken, de rechtsont. warring: „réduire en un seul corps d'ordonnances tout ce qui est; nécessaire pour establir la jurisprudence fixe et certaine" 5 ), ter ver. mijding van ,toutes les différences qui se rencontrent dans la jurisprudence: des compagnies" "). Maar met éćn slagr wordt dan de wensch des konings, de nationale rechtseenheid bereikt: „réduire tout son royaume sous. une mesme loi" 7).

De wetgeving zelve houdt geen uitvoerige anwijzingen in voor het doel van het koninklijk streven. Maar het motief der nationale rechts-

1) Tettre torite à un de ses amis, bij Lamoranon, Recueil des arrêtés, Paris 1783, I, bl. XVII-X XVIII.

3) D. t. p., bl. XVIII.

3) Rec. des arrếtés, le p., titre $I_{1}$ art. 1 .

†) D. t. p, bl. XXXi.

5) Mémoine utur la réformation de la justice (15 Mei 1665), in Lettres, instructions el minoires de Colbert, uitg. Clément, Paris 1869, VI, bl. 6.

a) D. t. p., bl. 9 .

7) Discours pour le conseil de la justice (10 October 1665), d. t. p., bl. 14. 
eenheid wordt toch tweemaal voor het procesrecht naar voren gebracht. De Ordonnance ciwile van 1667 klaagt in de voorrede, dat de wetten der voorgangers nétoient observées différemment en plusieurs de nos cours, ce qui causoit la ruine des familles par la multiplicité des procédures, les frais des poursuites et la variété des jugemens" 1). Daarom moet er nu komen "un style uniforme dans toutes nos cours et siéges" 2). Nog eens wordt de wensch ondèr woorden gebracht in een déclaration van 1673: "comme il importe de rendre la procédure uniforme dans toute l'étendue de notre royaume... et qu'il importe que... les procédures judiciaires soient d'un style uniforme" 3 ). Doch ook de rechtsontwarring ter zelfde plaatse wekt de aandacht. "Comme il n'y (a) point d'instruction qui doive être plus simple" zoo wordt de Ordonnance pour la réformation de la justice van 1669 ingeleid $\left.{ }^{4}\right)$. Ook de Ordonnance de la Marine van 1681 heeft een open oog voor de kwal: ${ }_{n}$ il étoit important de fixer la jurisprudence des contracts maritimes, jusqu'à présent incertaine" 5). Teekenend voor de rechtsverwarring, tegen welke de koninklijke wetgeving optreedt, is ook de nu in zwang komende en sindsdien gebruikelijk gebleven slotformule van de grootere ordonnances: „abrogeons toutes ordonnances, coutumes, lois, statuts, réglemens, stiles (of styls), et usages différens on contraires anx dispositions y contenues" ${ }^{6}$ ).

Met de Ordonnance de la Marine bereikt de wetgeving van Lodewijk XIV haar hoogtepunt. Maar daarmede was de belangstelling voor de codificatie ook nagenoeg uitgeput. $Z_{i j}$ herleeft krachtig onder Lodewijk XV. Zooals onder Lodewijk XIV CoLBsRT er in geslaagd was, de nationale aandacht, aan het vraagstuk gewịd, te leiden in de officiëele banen van den wetgevenden arbeid, zoo staat onder Lodewijk $\mathrm{XV}$ in het middelpunt der beweging en der wetgevende staatsbemoeiing de kanselier van het koninkrijk, Daguesseav. Een aanzienlijk deel van diens arbeidzaam leven is aan dit werk besteed. Het is hier onze taak niet, dit ondernemen in zijne vele uitingen te schetsen. Voor

1) Elders schrijft de koning de „incertitude des jugemens qui est si préjudiciable à la fortune de nos sujets" toe aan de verwaarloozing van de studie van het Romeinsehe recht. Edit touchant l'élude du droit civil et canonique otc. van 1679, bij IsAMBERT, XIX, bl. 196.

3) IsAMHERT, XVIJI, bl. 105.

3) ІІамав

4) Istmiskir, XVIII, bl. 341.

5) Isament, XIX, bl. 283. De gegchriften van SAvary verspreiden geen licht over het hoogere doel, dat hem bij zijn ondernemen heeft geleid.

b) B. v. Isamber'T, XVIII, bl. 185. 
ons is de rragg: naar welk ideaal streefde Daguesseau, toen hij de openbare meening voorlichtte en opwekte in zijne geschriften, toen hij de commissies voor de wetgeving instelde, toen hij de rechtsgeleerden en met name de rechterlijke macht van heel het land tot medewerkin en samenwerking uitnoodigde, torn hij ten slotte de gedeeltelijke codificatie van eenige belangrijke brokstulken van het privaatrecht wist tot stand te brengen?

De rechtshervorming in grootsehen stijl bedoelde DaGuesseau en zi.j is hen voor den geest blijven staun, ten einde toe. "Un seul corps de législation", "une loi générale pour les provinces", of nog vollediger gezegd "réduire toutes les coutumes à une seul, qui seroit la loi générale de toutes les provinces régies par ce qu'on appelle le droit français", zoo wordt de taak bij zijn optreden gesteld 1). En aan dit grootsch opgezette plan is hij getrouw gebleven: "le grand et vast! dessein de faire un corps entier de législation, dans lequel on recueilleroit, comme dans un seul code, toutes les lois", zoo schreef hij in een omzendbrief van het jaar $1728^{2}$ ), toen de ontzaglijke moeilijkheden, die de uitwoering bleek mee te brengen, hem al voorloopig tot de codificatie bij gedeelten had doen besluiten. Zoo was de opzet. Wat had Daguesseau daartoe bewogen? Ook hij was diep getroffen door de hopelooze en in alle richtingen noodlottige verscheidenheid en onzekerheicl der wetgeving: „la multitude et la variété des lois qui sont en usage parmi nous sont si grandes, qu'il arrive souvent qu'on n' en étudie presque aucune, par la difficulté de les savoir toutes" 3). Die verseheidenheid. is in de eerste plaats geteekend als nationale ongelijkheid, de uiteenloopende ongelijkheid van rechtsi'egeling in de verschillende deelen des. rijks: „les provinces... sont régries par des lois différentes, et quelquefois contraires les unes aux autres"; dat is de "diversité ou ... la contrariété des contumes" "4). Voor de rechtsverwarring als gevolg van de veelheid der rechtsbronnen ter ééne en zelfde plaatse heeft Daguesseav niet zoo scherp onderscheidend oog. Toch ligt dit euvel ten grondslag aan de klacht "que dans un mème royaume il y ait presque autant de lois différentes 'qu'il y ait de villes on de baillages" "5), want al die

1) Mémoire sur les aues génírules quo l'on peut avoir pour lu riformution de la justice. Oeuves, uitg. Paruessus, Paris 1819, X.IIT, hl. 200, 205 en 207.

2) Mémoire pour parutair à concilier les dioersités de jurisprudence (1728), Oenores, XIII, bl. $229-230$.

3) Oeutres, Xill, bl. 200.

") Omzendbrief van 10 Nov. 1728. Oenvres XII, bl. 281.

5) Dewtres, XIII, bl. 207. 
steden en baljuwschappen maken groepsgewijze deel uit van een provincie en worden dus mede door een gewestelijke coutume geregeerd.

Daguessead brengt ook het motief der rechtoonveiligheid onder woorden, dat wij in den aanvang van de vorige afdeeling als het derde hoofdmotief van het codificatoire ingrijpen bebben aangegeven. Onder Lodewijk XIV schijnt dit, althans voor het civiele recht, nog geen gewieht in de schanl te leggen. Voor Dagonsseau speelt het een rol van beteekenis: „quioiqu'il ne s'agisse que de l'exécution des mêmes lois, les juges les expliquent d'une manière si différente, qu'il en résulte, sur certains points, des maximes et des jurisprudences directement opposées dans les divers tribunaux de ce royaume; e'est un abus..." En "l'indécence de cette diversité de maxime" is noodlottig: "rien n'étant plus contraire à l'honneur de la justice et de ses ministres, que de voir que ce qui paroît juste dans un tribunal soit regardé comme injuste dans l'autre, quoiqu'ils ne jugent tous deux que sur les mêmes lois" 1). Reeds in 1715 zon Daguesseau op middelen om een einde te maken aan „les diversités de jurisprudence qui se trouvent entre les différens parlemens et cours de ce royaume" 2). En gedurig komt hij op dit punt terug ${ }^{3}$ ). De wetenschap kan hier, door hare voorlichting, énheid ran beginselen brengen. Zij poogde dit al sinds lang te doen, gelijk wij reeds hebben gezien. Ook Daguesseau heeft dit begrepen en hij, de onvermoeibare, heeft het niet versmuad, in die richting werkzaam te zijn. En hij schreef de Maximes tirées des ordonnances, suivant l'ordre du Code Henri ${ }^{4}$ ). De koning kon ingrijpen, want hij zag het als een misbruik. Maar wat de wetensehap en de koning zoolang tevergeefs hadden nagestreefd, dat kon met éen slag de codificatie bereiken, „afin que ceux qui veulent acquérir la science du droit, soit pour défendre les intérêts des plaideurs, soit pour en être les juges, eussent une espèce de code, qui devint le sujet fixe et certain de leur application" 5 ).

Den neerslag dezer denkbeelden vinden wij terug in de wetgeving van den tijd. Men houde daarbij in het oog, dat de groote ordonnances

1) Oeuvres, XII, b]. 281.

2) Mémoire sutr la projet d'établir un comseil pour la réformation de la justice (1715) Oeuvres, XIII, bl. 196.

3) Mémotre 1728, Oewures, XIII, bl. 229; Lettre oirculaire 1728, Oeuvres, XII, bl. 280.

1) Deutres, XIII, bl. 272-339.

5) Deutres, XIII, bl. 200. 
van Lodewijk XV alle door Da Duessenu zijn voorbereid, ook die, welke zijn uitgevaardigd in de jaren, waarin hij het kanselierschap niet b?kleedde $(1722-1737)$. De verstrekkende belofte wordt door den koning anngekondigd in 1731: "le corps des lois qui seront faites dans cette vue (de ne pas permettre de tolérer plus long-temps une diversité cle jurisprudence qui produit de si grands inconvénients") 1). Voorloopig stelt de koning zich echter met gedeeltelijke codificaties tevreden en daarbij blijft het ook. Hare motiveering spreekt geheel de taal van DAGUESSEAU en brengt de dubbele gedachte naar voren, die zijn wetgevend ondernemen bezielt: het streven naar nationale rechtseenheid tegenover de plaatselijke verscheidenheid der rechtsregelingen eenerzijcls (waarbij ook hier, naar het voorbeeld van DaGubssen o, de verseheidenheid in dẹ nationalen rechtskring en de veelheid der rechtsbronnen ter zelfder plaatse niet afzonderlijk worden in het vizier genomen), tegenover de willekeur der rechterlịke uitlegging anderzijds. De eisch der „uniformité" in dezen dubbelen zin wordt onophoudelijk op den voorgrond geschoven als het hoofdmotief van het wettelijk ingrijpen. Zoo doet de Ordonnance sur les donations van 1731: . La justice devroit être aussi uniforme dans ses jugements que la loi est une dans sa disposition;... il n'est point de lois qui ne renferment le voeu .... de l'uniformite... cette uniformité parfaite qui n'est pas moins hónorable au législateur qu'avantagense à ses sujets". Zij stelt zich roor te brengen "un? telle conformité dans les divisions, que, si les plaideurs ne sont pas assez sages pour être leurs premiers juges, ils sachent au moins qu? dans tous les tribunaux ils trouveront une justice toujours semblablis a elle-même par l'observation constante des mêmes règles" "2). Zoi). doet de Ordonnance concemant les testaments van 1735 in nog besliater taal. Als doel wordt daar gesteld "de faire cesser toute diversité de jurisprudence entre les différentes cours de notre royaume ... de rendr's la jurisprudence entièrement uniforme dans les tribunaux de notr's royaume... l'établissement $d^{\prime} u n e$ règle fixe et certaine... . que l'in.. certitude ou la variété des maximes ne soit plus désormais une matière toujours nouvelle d'inquiétude pour les testateurs, de dontes pone les juges.... en éloignant tout ce qui peut rendre les jugements incer.. tains et arbitraires" 3). En de derde groote Ordonnance, concernant les substitutions, van 1747, is gehcel in denzelfden toon gehouden:

1) Ordonnance sur les donations, Isamment, XXI, b1. 344.

2) Isamuent, XXI, bl. 343 en 345 .

3) Isambent, XXJ, bl, 387 en 388. 
"de faire ecsser l'incertitude et la diversité des jugements qui se rendent dans les différents tribunaux de notre royaume, quoique sur le fondement des mêmes lois.... d'établir la même uniformité de jurisprudence... prévenir toutes les interprétations arbitraires par des règles fixes et uniformes" "1).

Inmiddels had het werk der rechtsgeleerden niet stilgestutan. De lijn, welke Dumoucıs en rijne voorgangers hadden aangegeven, wordt doorgetrokken: langs DoMat tot op Porthizk, Ook zij streefden naar eenheid en ontwarring; aan hun arbeid lag, nitgesproken 2) of niet, het denkbeeld ten grondslag, dat de wetenschappelijke bewerking an de verwarde stof, dus aan het verwarde rechtsleven, eenheid en klarheid zou brengen. Zij hebben an de codificatie het stille, man reusachtige aandeel der niet bedoelde voorbereiding gehad. Zij werden gelokt door hetzelfde ideaal, dat ook de codificatiebeweging nijoeg, naar zij wisten het maar weinig, dat zij daardoor ook de coditicatie in de hand werkten. En de meesteu hunner - dauronder de grooten in de eerste plaats zwijgen over de codificatie als middel ow het doel te bereiken. Slechts enkelen hunner zijn zich van den samentang bewust, begrijpen, dat hun wetenschappelijk werk voorbereidt wat de wetgever voltrekken moet. In de eerste plaats is hier Bretonnier te vermelden. Bretonnier heeft twee boeken geschreven: de Observations en het Recueil. Het cerste heb ik niet in handen kunnen krijgen. Daarbij schijnt de toeleg te hebben voorgezeten "de rendre la jurisprudence uniforme"' ${ }^{3}$ ). Zoo kondigt ook

') Isnзиғнт, XXI, bl. 193 en 194. Zoo ook de kleinere ordonnances: Bdil concernant les auccessions des mères à leurs enfants, 1729: ,incertitude perpétnelle dans la jurisprudence; en sorto que non-seulement les diffërents tribunaux ont jugé différemment des questions entièrement semblables, nuis que dans le nème tribunal elles n'ont pas taujours été décidées de la mème manière". Is.nnewr, XXI, bI. 324. - Déclaration concernant la forme de tenir tes registres des bratimes eto, 1736 : "pour établir un ordre certain et uniforme". Isannler, XXl., bl. 406. - Ordannance comcarnant le farkx, 1737; "la diversité des opinions et la différente manière d'expliquer les mêmes dispositions ont produit nne si grande variété dans les usages de plusieurs tribunaux ... une loi pour parvenir dे cette uniformite parfaite". Istmuerr, XXI, bl. 2 en 3. - Réglement concenant la procédure alu vonseil, 1738: „réunir

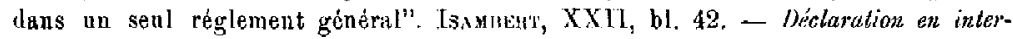
prétalion de loodonatance sar les textaments, 1751: "ath qu'il n'y ait it l'avenir aueune différence dans les jugements sur cette matière dans tous les tribunaux de notre royaume". Istribliti, XXIl, bl, 248.

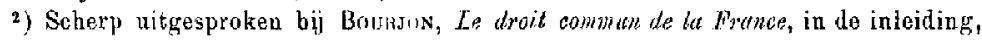
die hare gedachte samenvat in dezen eisoh: „former ce corps complet", uitg. 'Paris $1770 \mathrm{~T}, \mathrm{bl} . \mathrm{e}$.

3) Recueil, bi. LVII. 
het latere, meer bekende en meer verspreide, geschrift zich zelf aa:1: Recueil par ordre alphabéfique des principales questions de droit, qui se jugent diversement dans les différens tribunaux du royaume. Avec d'es réflexions pour concilier la diversité de la jurisprudence, et la rendre uniforme dans tous les tribunaux 1). Toch is de opzet der verhandeling minder breed on minder gedurfd dan de titel belooft. De eenheid van het costumiere recht schrikt Bretonyier bier nog af 2 ). Maar voor het droit écrit kan de eenvormigheid bereikt worden. Daartoe moet de wetenschappelijke bewerking dienen, welke hij zelf onderneemt, waarna de wetgever - dat was in die dagen de.koning - het aldas voorbereide, met zijn groot gezag regelt ${ }^{3}$ ). Daarbij wordt als motief op den voorgrond geschoven de behoefte aan rechtsveiligheid tege:aover de rechterlijke willekeur: "chaque parlement, chaque tribuncl, chaque juge l'interprete suivant ses lumières, son goût et son caprice" 4:).

Terwijl de juristen vooral in stilte werkten, gingen er in het lar:d andere stemmen op tot voorlichting van de openbare meening en tot opwekking van het centrale gezag. Ook daaruit leeren wij wat ile tijdgeest van de codificatie verwachtte. In de vroegere regeeringsjaren van' Lodewijk XV ontmoeten wij hier de figuur van den merkwaardigen kinderlijken idealist, die zijn naam verbonden heeft aan den strijd tegen zoovele misstanden der eeuw in Frankrijk en daarbuiten, den warhoofdigen, toch geniaal aangelegden, bovenal in-goeden "beroeps-ontwerper", den onvermoeibaren abbé DE Sr. Pierre. Ook de kwalen van het rechtsleven hebben zijne aandacht en dadelijk heeft hij een ontwerp ter verbetering gereed: Mémoire pour diminuer le nombre des procés ${ }^{5}$ ). Duaruit klinkt ons tegen de roepstem van den leek, die oog heeft roor den nood des tijds. Het is van belang na te gaan, hoe hij dezen begrijpt. Vóór alles treft hem de bonte nationale verscheidenheid der rechtsregelingen, in de eerste plaats van het costumiere recht, ${ }_{n}$ nos Ioix coutumières sor:t diférentes et opposées entre elles sur plusieurs matieres"; maar ook in de landen ran. bet droit écrit ontbreekt de eenvormigheid, „plusieurs

1) Nouv. ed. Paris 1753.

2) "Chose trop difficile, et pour ainsi dire impossible; car la même cause qui a fait introduire les coûtumes, les a fait naitre toutes différentes et même presque toutes contraires, parce que ceux qui les ont établies avoient des vîës différentes ut des intérêts opposés". Recueil, bl. LVIXI.

3) D. t. p.

1) D. t. p.

5) Paris 1725. 
loix romaines elles-rnêmes sur certaines matières sont interprétées et observées diféremment parmi nous en différens parlemens" 1). Of, samengevat: "les loix des diférentes provinces sont souvent opposées entre elles" 2). Maar ook voor de andere ziekte van het rechtsleven, voor de verscheidenheid ter plaatse, heeft hij open oog, "les loix d'un canton d'une même province sont sonvent oposées aux loix generales de la province" "). Die twee samenwerkende oorzaken riepen den wantoestand in het leven: „le droit fransois... est demeuré ... très bigaré et très diforme", en "cette étrange diformité est préjudiciable aux particuliers et à l'état" t). Het redmiddel uit den nood is de codificatie: „que le roy rendit peu à peu ces loix uniformes et generales pour tout le royaume" 5). De nadruk valt hier op "peu à peu", want ditmaal maant de in den regel zoo voortvarende abbé tot bijzondere omzichtigheid. Van een hervorming, die met één slag het gansehe s'echt omvat, wil hij niet weten. De codificatie moet bij stukken en brokken worden tot stand gebracht. Alleen dan heeft zij kans van slagen ${ }^{6}$ ). En op dit punt schijnt de abbé De St. Pierre zelfs Daguesseau te hebben overtuigd en zoo een zekeren invloed te hebben geoefend op de codificatiepolitiek der regeering ${ }^{7}$ ).

Van de groote publicisten der XVIIIo eeuw noem ik nog Voltaike. De wantoestand op het stuk der rechtsregeling heeft mede zijne spottende ergernis gewekt. De kunstenaar, die heftig uit-zegt wat hij voelt en ziet, wiens aangewezen taak het is, veeleer te overreden dan te overtuigen, heeft het reeht te overdrijven. Van dat recht heeft VoLTaIRE ruimschoots gebruik gemaakt. $\mathrm{H}_{i j}$ doet dit ook nu, wanneer hij ons het Frankrijk zijner dagen, uit een oogpunt van wetgeving bezien, schildert als een tafereel van krankzinnige verwarring ${ }^{8}$ ). Maar ook die overdrijving is leerzaam in hare duidelijkheid. Die verwarring ziet hij in de eerste

1) Bl. 6-7.

2) Bl. 17 .

3) D. t. p.

ל) Bl. 7 .

5) Bl. 17--18. Nader wordt deze eisch omschreven bl, 36-37, uitgewerkt bl. $69-92$.

6) ${ }_{n}$ Le (projet) restraindre ì former de tems en tems les ordonnances faciles d mettre en loi generale tantât sur une des 24 matiéres tantôt sur une autré" B!. $19-20$.

7) ViOLLET, t. a. p., bl. 248.

a) „De quelque eôté qu'on jette les yeux, on trouve la contrariêté, la dureté (dit geldt voor hot strafrecht), l'incertitude, l'arbitraire". Précis du siecle de Lotis $X F$, Oeuvres, uitg. Renouah, Paris 1819, XIX, bl. 384. 
plaats weer als een uitvloeisel van de bonte veelheid der honderd vier en veertig ${ }^{1}$ ) of, zooals hij het elders voorstelt, der vijf honderd veertig coutumes ${ }^{2}$ ), die het land verdeelen in even zoovele kleine staatjes ${ }^{3}$ ). En hij stelt haar aan de kark in hare gevolgen, die ,prodigieuge contrariété entre les lois du même royaume" 4). Maar ook de andıre verwarring, de verwarring ter plaatse zelve binnen-den kleineren rechtskring - „confusion intolérable" - teekent hij in scherpe lijnın. In het normencomplex vinden wij: overblijfselen van feodale wetgeving, daarnasst de "lois romaines.... au nombre de quarante mille", daarnaast coutumes 5 ), daarnaast allerlei wetten "faites à mesure, au hasard, irrégulièrement, comme on bâtissait les villes" "6). Zoo gebeurt het dan, dat „dans le même parlement, la maxime d'une chambre n'est pas celle de la chambre voisine" 7 ).

VOLTAIRE, het „negatieve genie”, is ook hier geweldig bij de afbraık, onmachtig bij den opbouw. Wanneer het er op aankomt, den weg te toonen, die uit het moeras der dubbele rechtsverwarring voeren moet, dan weet de man, die de heele wetgeving van tafel wil blazen, daarvior niets anders in de plaats te stellen dan enkele goedkoope annijzingon, in welker algemeenheid wij met eenige moeite nog juist het verlangen naar de codificatie kunnen onderscheiden: "qu'il .n'y ait qu'.... une coutume ... q que toute loi soit claire, uniforme et précise" 8).

\section{VI.}

Zoo aijn wij genaderd tot den vooravond der Revolutie. Want

1) Dictionnaire phitosophique, in $\mathrm{v}^{\circ}$ Contumes, Oeuvres, $\mathrm{XXXV}$, bl. 8 .

2) Précis, Oeubres, XIX, bl. 382.

3) Dict. phil. in $v^{\circ}$ Lois, Oeutres, XXXVII, bl. 170.

1) Précis, Qeuvres, XIX, bl. 382. "Faut-il que le même homme ait raison en Bretagne et tort en Languedoo? Qui dis-je? il y a eutant de jurisprudences que de villes... de sorte qu'un homme qui court la poste en France, change de lois plus souvent qu'il ne change de chevaux". D. t. p. bl: 381 en 382 . De laatste vergelịking ook Oenvres, XXXV, bl. 8.

5) Oenores, XIX, bl. 381 en 382

ค) Oeuvres, XXXVII, bl. 170. En daaraan wordt toegevoegd: „Voyez a Paris le quartier des Halles, de Saint-Pierre-ang-boeufs, la rue Brisemiche, celle da Pot-auDiable, contraster avec le Louvre at les Tuilleries; voilà l'image de nos lois."

7) Oeutres, XIX, bl. 381 .

3) Dich. phil. in $\mathrm{v}^{\circ}$ Lois eiviles et ecclésiastigues. Oeav'es, XXXVII, bl. 187. Het betoog van den Précis du siècle de Louis $X F$ eindigt met deze fraaie opwekking: "Nous cherchons dans ce siècle à tout perfectionner, cherchons donc d̀ perfectionuer les lois." Oeuvres, XIX, bl. 385. En dat is al! 
voor het privaatrecht wordt onder en door de regeering van Lodewijk XVI niets van beteekenis meer tot stand gebracht.

Wanneer wij nu het brok geschiedenis dat roor ons ligt, overzien, dan leert ons het gegeven overzicht dit: de codificutiebeweging in haren nieuwen vorm, gelijk zij in de XVle eeuw als landswetgeving werd ingezet - in tegenstelling tot den daaraan vooraf'gaanden tijd, wiens streven op vastlegging vau gewestelijk en plantselijk recht was gericht, - - die codificatie wordt bezield door deze dubbele gedachte: rechtsvereenvoudiging en rechtseenvormigheid, warbij soms zich voegt het ver. langen naar rechtaveiligheid. De rol van dit derde motief is voor het privaatrecht bescheiden. En voor het strafrecht èn voor het constitutioneele recht is dit anders. Daar staat integendeel de rechtsveiligheid als stuwkracht der codificatie op den voorgrond. Maar ook op het atak van privatrecht is zij onmiddellijke anleiding voor het rechtsopteekenend ingrijpen of het verlangen daarnaar, in dien zin dus hoofdmotief.

Rechtsvereenvoudiging, rechtseenvormigheid, rechtsveiligheid zijn dus de drie groote ondersoheiden, tevens verknochte rechtsgeduchten der codificatie, welke wij hebben onderzocht. Maar wij zouden in de riel van het verschijnsel njet gehecl doordringen, zoo wij ons met dit gegeven vergenoegden. De drievoudige leuze van rechtsvereenvoudiging, rechtseenvormigheid, rechtsveiligheid klinkt ons dadelijk luide tegen als een fanfare, wannees wij de codificatiebeweging volgen in den loop harer ontwikkeling. Maar wanneer wij. scherp het oor te luisteren leggen, vernemen wij nog andere, meer gedempte klauken. Du kernmotieven rijn niet de alleen-werkzame.

Al dadelijk heeft de codificatie mede bezieling ontrangen van een streven, dat als ran zelf sprekend op moest komen bij een beweging, die stuurde naar verandering op gropte schaal. De codificatie heeft natuurlijk ook rechtsverbetering gezocht en met de daad rechtsverbetering op groote schaal gebracht, materiëele verbetering, volmaking, ontwikkeling. van het normeneomplex. Ook in dit opzicht is het doelbewuste streven gericht geweest telkens op het eigen object, dat ter verbetering van zelf was angewezen; het privatucht heeft bovenal gebracht de gelijkstelling van allen voor de wet, het strafrecht heeft de onmenschelijke wroedheid afgeschud, het staatsrecht heeft het volk medezeggenschap an het stuatsbedrịf gegeven. 'Toch moeten wij scherp toezien, om ons hier niet door den schijn te laten verblinden. De politiek van rechtsverbetering is uen gelegenleidsdoel van de codificatie geworden, zij is niet voor haar een eigonlijke of specifieke stuwkracht geweest. De codificatie was het specifieke red- 
middel om te geraken uit het moeras der rechtsverwarring, der rechisverscheidenheid, der rechtsonveiligheid. Rechtsverbetering, daarentegen, kan langs vele andere wegen worden bereikt. Zij behoeft niet juist de samentrekking van alle recht in een massa-wetboek. Men was zich daarvan ook zoo wel bewust. Nu en dan vinden wij dit bewustzijn duidelijk uitgesproken.

Hoor CoLBERT met onverbeterlijke helderheid het specifieke doel der codificatie kenschetsen naast het gelegenleidsdoel der rechtshorvorming. Wij hebben hierboven gezien, wat CoLberT in de eerste plaats van de codificatie verwachtte. Daarnaast versmaadde hij allırminst de rechtsverbetering: „peser solidement tout ce qu'il y aura à changer et corriger" 1). Maar daartoe is de codificatie niet onontbeerlijk: „Si Vostre Majesté s'est seulement proposé de recevoir de toutes parts les mémoires des choses qui seront à réformer pour une plus parfaite administration de la justice dans son royaume, il suffira d'examiner les matières... et d'y apporter les remèdes que sa pruderce estimera nécessaires. Mais si Vostre Majesté s'est proposé quelque plus grand dessein, comme serait celuy de réduire tout son royaume scus une mesmi loi..."2). Dan eerst wordt de codificatie noodig! Onder Lodewijk $X V$ heeft Daguessead denzelfden kijk op het vrakgstuk. Hij onderscheidt zeer duidelijk de rechtsverbetering nil s'agirjit de réformer les lois anciennes, d'en faire de nouvelles", maar daarna volgt eerst de codificatie: "réunir les unes et les autres dans un seul corps de legislation" 3). En eenmaal heêft ook de koning zelf het mooi geformuleerd: "Notre intention n'est point de faire... un changement réel aux dispositions des lois... nous roulons au contraire en affermir l'autorité", 4) zoo wordt de ordonnance van 1735 anņ̧ekondigd, die nochtans het testamentaire erfrecht poogde te codificeerun.

Er is een tweede bijkomend motief dat de aandacht vraagt: in Frarkrijk en elders, nu en later, heeft de neiging bestaan, de unificatie van het recht uit te buiten als een middel ter versterking en voltooiing der staatkundige eenheid. Het is in dit opzicht zeer sprekend, dat juist het tot éénheid groeiende Frankrijk van den H. Lodewijk en het tot de éenheid terugkeerende Frankrijk van Lodewijk XI venge codificatieplannen hebben gekoesterd. En het is belangwekkend, na te

1) Mémoite sur la réformation de la justice, vermelde vitg, VI, bl. 9.

2) Discours pour le conseil de la justice, VI, bl. 14.

3) Mémoire pour la réform. de la just., Oeuvres, XIII, bl. 200.

4) IsAmbert, XXI, bl. 387 . 
gaan, hoe heel de gesebiedenis door, telkens de eenheid van wetgeving genoemd wordt in één adem met de éénheid van maten en gewichten, als drie nummers van eenzelfde program. Vooral bij Domoulis spreekt het staatkundig motief begrijpelijkerwijze een krachtig woord mee. De eenheid van wetgeving was roor hem een van de vormen van de eenheid des lands, waarvoor hij zijn leven lang onvermoeid heeft gestreden. In de boven besproken Oratio wordt dan ook mede de nadruk gelegd op de "ratio regni confirmandi", aldus toegelicht: "Mihi quoque videtur nihil optius, nihil efficacius ad plures provincias sub eodem imperio retinendas et fovendas, nec fortius, nee honestius vinculum, quam communio et confermitas eorumdem morum legunve utilium et aequabilium" 1). LoIsn: beziet de eenheid van wetgeving eveneens uit den gezichtshoek van de staatkundige eenheid. Zijne opvatting werd, in ander verband, hierboven reeds weergegeven ${ }^{2}$ ). Ook de eeuw van Lodewijk XIV moest de veelheid der rechtsregelingen begrijpen als een net van scheuren, dat het hechte gebouw der nu bijna volkomen bereikte nationale eenheid ontsierde en bedreigde. En de raadgevers des konings houden dezen de codificatie voor oogen als cen middel om dat hoogere doel te bevorderen. Colbert gaf daaraan den vorm, dien wij al kennen : „réduire tout son royaume sous une mesme loi, mesme mesure et mesme poids" 3). En Lamolgnon hoopte eveneens door middel van de codificatie te kunnen bestrijden „cette multiplicité de loix contraires, qui rend les différentes provinces d'un même royaume étrangères les unes aux autres et en quelque sorte cnnemics" 4). Onder Lodewijk XV klinkt ook in deze richting de stem der publicisten. VolTaIRF roept uit: „Il est dans une seule province de l'Europe, entre les Alpes et les Pyrenées, plus de cent quarante petits peuples qui s'appellent compatriotes, et qui sont réellement étrangers les uns pour les autres, comme le Tunquin l'est pour la Cochinchine" 5).

Ten slotte komt, als bijeenkomstig motief voor het codificatoire ingrịppen, nog in aanmerking: de roemzucht der vorsten. De koningen,

1) Opera, II, bl. 691,

2) Zie hierboven bl. 206.

3) Discoturs pour le cortseil de la justice, t. a. p., VT, bl. 14.

1) Vie de Lanoignon, hierboven vermeld, bl. XXXI. Een latere biograaf van LA. MoIGNoN, RtCHER, segt ven hem: „Il croyait que rien n'etoit plus cupable d'uffoiblir les liens qui doivent réunir toutes les portions d'une monarchie, que cette varièté d'asages singuliers, souvent bizares, toujours contraires les uns aux autres". Recueil des arrétés, uitg. Paris 1777 , bl. IV.

s) Dict. phil. in $\mathrm{v}^{\mathrm{O}}$ Lois, Oeutres, XXXVII bl. 170. 
die een gretig oor leenden aan de hun voorgelegde hervormingsplannen, waren niet alleen koningen, die een open oog hadden voor de $\mathrm{kwalen}$ van hunnen tijd of die de verpersoonlijking waren van den krachtigen eenheidsstaat. Het waren ook koningen, die droomden van onsterfelijkheil. Hendrik III schijnt iets van den roem van Theodosius en Justinianus te hebben voor oogen gezweefd, toen hem de Code Brisson, die bestemd wø.s zjjn naam te voeren, werd voorgelegd ${ }^{1}$ ). Toen Cinarondas zijn Code Henri IV 2) opstelde, hield hij den vorst een zelfde lokaas voor: nafin que ce Code Henry... soit mis en lumiere sous vostre nom et par vostre authorité, et la posterité cognoisse que vous scavez ausisi bien gouverner les peuples par les loix, que les dompter par les armes, quand il en est besoing" " 3 ). Heel de voorbereiding van de wetgeving onder Lodewijk XIV en de beraadslagingen zelf staan in het teeken van den vleitoon des tijds, die alle eer laat aan den vorst. Daarbij wordt de vergelijking met de groote wetgevers der Oudheid, Solon, Augustus, Theodosius, Justinianus, den koning gedurig ter opwekking voorgt,houden en telkens speelt de belofte der onsterfelijkheid voor den schepper en de schepping daarin door.. Eén greep zal ik doen uit de dwarrelende massa van die opgeblazen vleitaal. „Pour rendre cett:e nouvelle ordonnance immortelle, comme toutes les actions du roi, ot pour faire qu'elle parût dans tous les siecles dignes de la grandeur de son nom ..." 4). Zoo sprak, bij de beraadslaging over de ordonnance civile, de cerste magistraat van het koninkrijk, Lamorgnon. Ik heb met opzet niet een hoveling uitgezocht. Ook Daguesseav, hoeveel hij ook ten hove vertoefde, was allerminst een hoveling in den ongunstigen zin des woords. Zijne sobere opwekking, tot Lodewijk $X \nabla$ gericht, heeft dan ook niets van vleierij. Toch tracht hij den koning te brengen

1) Ik vermeld dit op gezag van Bassaud, Manzel dhistoire du droit français, Paris 1899, bl. 380 . Het is $\mathrm{m}$ ij niet mogen gelukken, dit gegeven terug te vinden in de bronnen van den tijd.

2) Zie hierboven, bl. 214 n. 1.

3) Epistre au Roy Henry le Grand, uitg. Paris 1609, bl. A III.

1) Procès-verbal des' confésences lenues pour l'examen des artieles de l'ordonnanse vivile, Paris 1776, bl. 479. Zie verder voor Lamorgnon: d. t. p., bl. 5 en bl. 476-479 (vergelijking met Solon, Theodosius en Justinianus); Fie de Laneignon, hierb. vormeld, bl. XXXI: "il vouloit que Louis XIV fût le Justinien de la France". Voor de Séguien; Procès-verbal, bl. 5. Voor Auzanet: Lettre, hierboven vermeld, bl. XX. Voor de beraadslagingen (met name de uitlatingen van Horman, Vors..N en DE Verthamont): Clemenrs, Lettres, inser . et mém. de Colb., hierboven vermeld, VI, bl. $370 \mathrm{vv.}$ 
onder de bekoring van het grootsche werk van voorgangers ${ }^{1}$ ). Maar ook in gezwollen stijl werd de roem van den koning-wetgever voor de eeuwen, aan Lodewijk XV voorgespiegeld. Daarvoor zorgde de abbé DE ST. PIERre in de opdracht „Au Roi" van zijn geschrift: „Le nom de Justinien, Sire, sera toujours célebre dans le monde, parce que oet empereur eut le bonheur d'entreprendre, et l'honneur d'executer durant son regne un projet semblable à celui-ci... Vous pouvez, Sire, faire beaucoup plus pour le bonheur de vos sujets, que Justinien ne fit pour l'honneur des siens... Vous deviendrez ainsi non-senlement le grand bienfaicteur de la nation fransoise, mais encore un des plus grands bienfaicteurs des homes... Vous mériterés que vos sujets, et la postérité la plus reculée... Vous distingue de tous les autres rois passez et futurs, par le surnom de Louis le Pacificateur, le plus beau titre, le plus précieux et sans comparaison le plus honorable de tous les titres..."2).

Ziedaar de rechtsgedachte der codificatiebeweging, hier bezien voor zoover zij het privaatrechtelijk gebied bestrijkt, welke het Frankrijk van vóór de Revolutie heeft bezig gehouden. Zoo bet beeld, dat ik in de groote lijnen heb trachten uit te teekenen, juist is, mag ik, samenvattend, de codificatie omschrijven als een daad - of het pogen daartoe - van massale rechtsregeling in de wet, ter wille van rechtsvereenvoudiging, rechtseenvormigheid en rechtsveiligheid, nijpende nooden des Tijds, beoogende tevens rechtsverbetering, bevordering der steatkundige eenheid en onsterfelijkheid van den wetgevenden vorst.

Dat streven is roor bet kleinere deel geslaagd, voor het grootere deel mislukt. De Revolutie is noodig geweest om de onderneming te verhaasten en te voltooien. Maar wanneer zij eindelijk het lang verwachte tot stand brengt, dan sluit zij in dit opzicht geheel aan bij het verleden, dan trekt zij de lijn door, die de eeuwen fóór haar hadden uitgestippeld.

1) Oenores, XIII, bl. 201-202.

2) Mémoine, hierboven vermeld, bl. A II-IV. 